\title{
On the Arrangement and Structure of the Vascular Strands in Angiopteris evecta, and some other Marattiaceae.
}

BY

\author{
J. BRETLAND FARMER, D.Sc., F.R.S., \\ Professor of Botany in the Royal College of Science, London,
}

AND

T. G. HILL, A.R.C.S.,

Demonstrator in Biology at St. Mary's Hospital Medical School, London.

With Plates XVI, XVII, and XVIII, and a Diagram in the Text.

$\mathrm{T}^{\mathrm{H}}$

HE Marattiaceae of the present day, comprised in some five or six genera, represent the relics of a group which in the Palaeozoic age formed one of the great dominant groups of vascular cryptogams. And now, though occupying a somewhat isolated position, they nevertheless exhibit features which point more or less vaguely to an affinity with several other groups of plants. It thus becomes a matter of some interest that a family of so great palaeontological importance should be as thoroughly understood as possible, and in particular that the structural details of anatomy should be accurately and fully known and appreciated. For it is largely on the anatomical evidence as arrived at by a study of the vegetative organs, that our views as to the relationships of these ancient plants for the most part depend.

But on turning to the existing memoirs on the anatomy of the Marattiaceae, one speedily discovers many lacunae in

[Annals of Botany, Vo1. XVI. No. LXII. June, 1902.] 
our knowledge, and many discrepancies in the statements made respecting even important details. Furthermore, there is not a single species concerning which we possess anything approaching a complete account of its structure at different periods of its development. This latter circumstance is largely due to the difficulty of obtaining suitable material; and it is because we have been fortunate in possessing a fairly complete series of young plants of Angiopteris evecta, Hoffm., supplemented by specimens of Marattia fraxinea, Smith, and Kaulfussia aesculifolia, Blume, that we venture to endeavour to fill in some of the gaps in our knowledge of these plants.

It is not to be expected that we shall be altogether successful in this attempt. Apart from the fact that there necessarily exists a certain degree of variety in the structure, even of individuals of the same species, there is always the difficulty of correctly appreciating the relative importance of anatomical details in connexions other than with those which happen to fall more or less immediately within the purview of the investigator at the moment. Details which in one decade appear to be trivial, may in the next assume an unexpected significance, and it is perhaps hardly possible for any anatomical treatise to be otherwise than tinged with the local colour of contemporary thought.

We desire at the outset to express our indebtedness to the Regius Keeper of the Royal Botanic Garden, Edinburgh, to the Director of the Botanic Gardens at Peradeniya, to Profs. F. W. Oliver and A. G. Tansley, and to Mr. H. Wright, for their kindness in supplying us with material that has proved of such value in supplementing our own stock.

Passing over the older references to the group, the first writers who seem to have endeavoured to deal seriously with the anatomy of the group were De Vriese and Harting in $1853^{1}$. In this Memoir the task of working out the anatomical characters appears to have been undertaken by the latter of the two collaborators. The results were very incom-

1 Monographie des Marattiacées, par W. H. de Vriese et P. Harting, I 853. 
plete, a circumstance partly perhaps to be ascribed to the small amount of material at his disposal.

The next paper of importance is the often quoted memoir of Mettenius (I864) ${ }^{1}$, who in a magnificent monograph really laid the foundations of our knowledge of the intricate distribution of the vascular strands. His specimen, as is well known, was a mature plant which was in a moribund condition when he investigated it, a fact which probably accounts for some of the anomalous characters met with near the apex. $\mathrm{He}$ clearly distinguished the concentric funnel-shaped zones of vascular strands which form so characteristic a feature in the bulky stems of these plants, and he corrected the mistake of De Vriese and Harting of not distinguishing the intracortical roots from the foliar strands. The leaf-trace bundles were shown to form the upward and outward continuation of the funnel-shaped lattice work, and he grasped the character of the anastomoses, whereby the exit of the traces was compensated for by branches from the next internal zone of vascular strands. The details observed by him in this connexion will be discussed later on in relation to the arrangements met with in the younger sporophyte. Mettenius's account is confirmed in all important details by Miss Shove ${ }^{2}$, who failed, however, to identify in her specimens the middle leaf-trace steles stated by Mettenius to originate from the next inner zone of bundles. This discrepancy may perhaps be explained as due to a difference in the stage of development of the plants in the two cases. Our own observations show that in young plants only the two stout lateral steles pass out to the petioles, all the rest being as yet in abeyance.

In 1889 a paper by Kühn appeared in 'Flora,' and dealt with ${ }^{1}$ the arrangement of the vascular strands in younger plants of Marattia and Angiopteris, as well as of Kaulfussia.

${ }^{1}$ G. Mettenius, Über d. Bau von Angiopteris, Abh. d. k. s. Ges. d. Wiss., ix.

${ }^{2}$ R. F. Shove, on the structure of the stem of Angiopteris evecta. Annals of Botany, xiv.

s V. R. Kühn, Untersuchungen ü. d. Anatomie der Marattiaceen u. Gefässkryptogamen. Flora, Bd. lxxii, I889. 


\section{Farmer and Hill.-Arrangement and Structure}

The minute anatomy of the vegetative organs was also described.

Kühn seems to have regarded as an essential character of the vascular arrangement in the stems of these plants, the presence of an axile strand or bundle which is surrounded by one or more rings of peripherally situated strands. The simplest condition is presented by Kaulfussia. In this Fern there is only a single ring of peripheral bundles. These anastomose with each other and give rise to the leaf-traces. Below the exit of the latter, the axile strand bends upwards and then gives off either two bundles, or a single one which immediately proceeds to fork, and the latter, by joining the peripheral ring, serve to close up the foliar gap. The axile strand from which they sprang then bends downwards, and resumes its old position nearer the ventral surface of the stem. Each leaf, situated obliquely to the right and left of the stem alternately, receives three main strands, whilst the roots spring from the lower strands of the dorsiventral stem.

Kühn regards the arrangement obtaining in Marattia as substantially similar to that of Kaulfussia, when allowance is made for the more radial character of the stem of the former. The young plant possesses a similar axile bundle situated in the middle of a ring of peripheral strands. But so far as we understand his account the mutual relation of these is not regarded as being quite alike in the two cases. In Marattia the axile strand is not considered as a single cauline bundle, but as made up of different ones at different levels. Thus the axile strand of one level passes to the periphery higher up, its (axile) place being taken by a bundle from the opposite side of the peripheral ring. The original axile strand finally passes out as one of the leaf-trace bundles. The closure of the foliar gap above, as in Kaulfussia, is said to be related to a strand which unites with the sides of the gap, but the details are rather more complicated. In the successive outer zones of bundles of older plants the gaps left by the exit of leaf-traces are said to be compensated in much the same way as stated by Mettenius. 
We have ourselves been led to form a somewhat different conception of the relations existing between the various branches of the vascular system, as will become apparent later on. The chief respects in which we differ lie perhaps in the direction of greater simplicity, for a study of the youngest plants shows that the complex arrangements met with in the older specimens are in reality susceptible of easy explanation. The primitive type can, when once understood, be readily discerned, in spite of the disguise produced by the remarkable degree of anastomosis and branching which the vascular strands undergo in these plants.

The method adopted by us in studying the relations and the development of the vascular skeleton in the young sporophytes of various ages has been as follows. Entire plants were cut by means of the microtome into serial sections, care being taken that all the sections were preserved and retained in their proper order on slides. From these the vascular tissue has been built up in the form of wax models. Sheets of wax are prepared of a thickness appropriate to the thickness of the sections, and the degree of magnification employed, and a tracing made on successive sheets of the vascular tissue in every section in its proper order. The drawings were then cut out, due care being taken to preserve the proper orientation, and the wax sections mounted one above another were then held in their places by inserting warmed needles and by carefully fusing the edges. Models prepared in this way, and with due precautions, are extremely accurate, and there is no danger of either missing or confusing even minute details of anastomosing and branching, such as must attend the most careful dissection. And it is of course far more easy to interpret such models, all the parts of which are true to scale, than is the case with a series of drawings however carefully prepared. The actual process of tracing and building up the models often involving several hundreds of sections for one plant, is doubtless tedious, but the clearness and certainty of the results more than repay the labour expended upon them. 
The vascular skeleton of the young sporophytes of Angiopteris evecta and Marattia fraxinea, and of the adult stem of Kaulfussia.

The vascular skeleton in the young plant of Angiopteris consists of an axile rod of tissue from which strands are given off to the roots and leaves respectively. The first lateral root is given off, as previously stated by one of us ${ }^{1}$, at a point not quite opposite the formation of the first leaftrace. It is separated from it by about $130^{\circ}$. The regular relation between the leaf and the corresponding root is, however, soon lost. The gaps produced by the early leaf-traces are very small and are immediately made good above. The first deeply depressed aperture or gap occurs at about the sixth or seventh leaf. The leaf-traces still continue to issue from the stele as single strands till a varying number have been formed, but they begin to bifurcate whilst still within the cortex of the stem. (Pl. XVI, figs. I, 2, 3.)

As the stem increases, the leaf-traces become more numerous and crowded, and they take away a larger portion of the vascular tissue from the axile strand. The result is that the leaf-gaps become less rapidly repaired. The stele is already hollow in this region (Fig. 3), that is, it consists of a cylindrical vascular mass with perforations corresponding to foliar gaps and enclosing a core of parenchyma. Sooner or later the gap above one leaf fails to be repaired till after the exit of the trace of the next leaf, and then the original vascular cylinder becomes broken up, and assumes a condition in transverse section conforming with that of polystely or dialystely.

When once this condition has supervened, the vascular ring is never again completely repaired; on the contrary, owing to the crowding of the leaves, more and more apertures or foliar gaps are visible at any one level in the cylinder. Finally, across the intervening parenchyma commissural vascular strands are differentiated, and these connect the opposite sides of the cylinder, which now exhibits the appearance of a coarse

${ }^{1}$ J. B. Farmer, On the embryogeny of Angiopteris evecta. Annals of Bot., vi, I 892. 



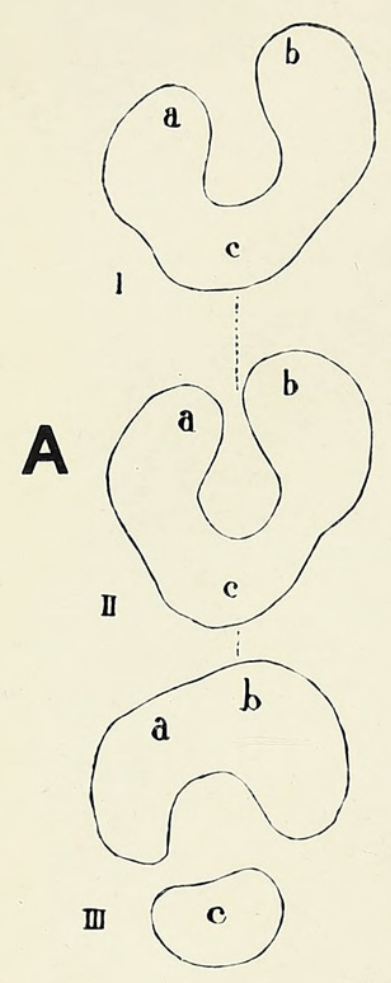

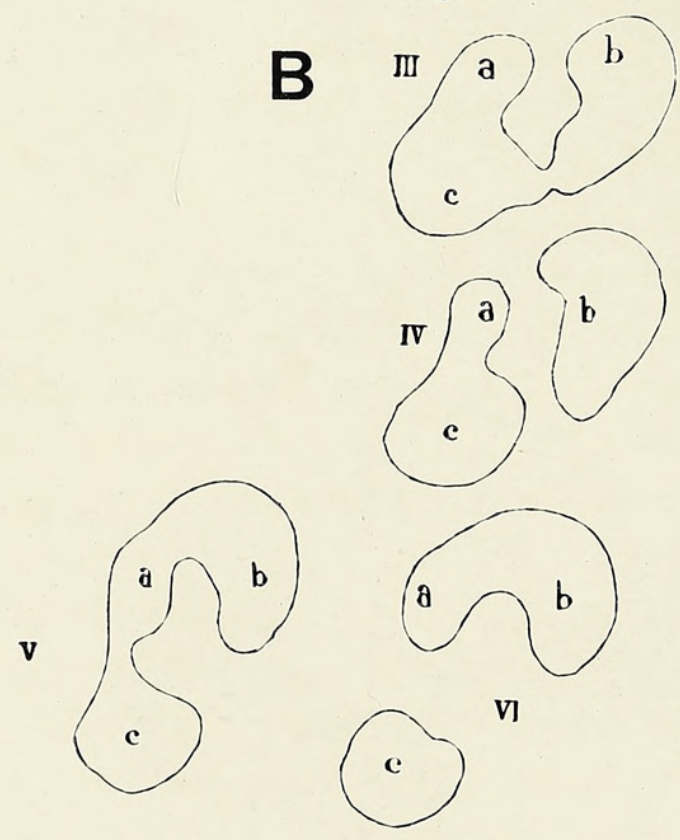
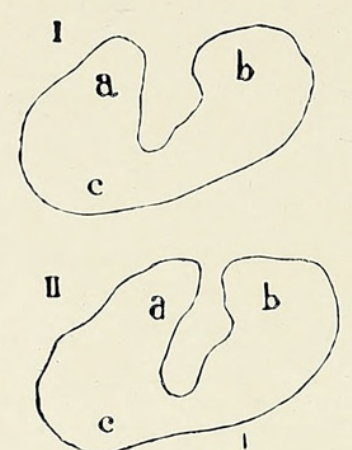

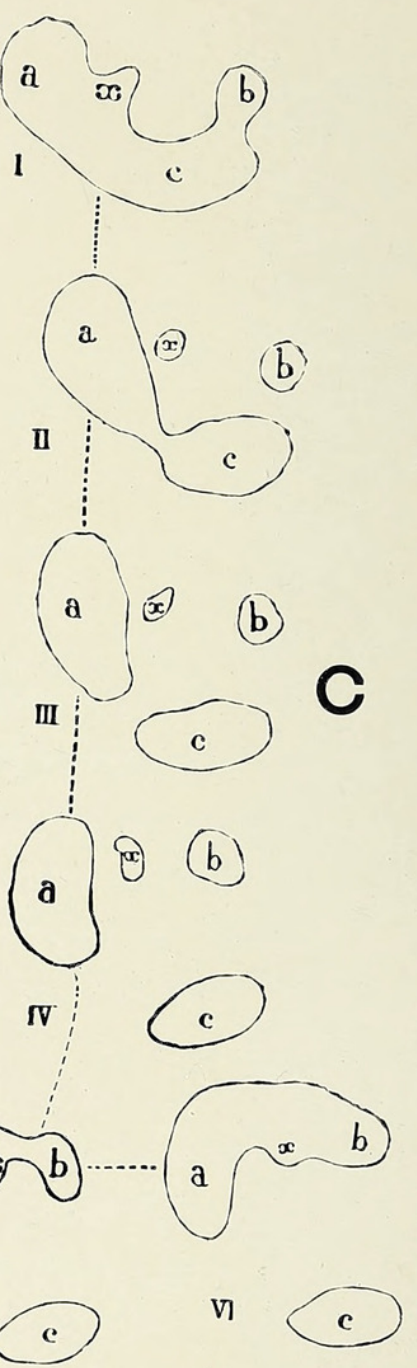

FIG. 2I. The figures illustrate in consecutive horizontal (transverse) sections the changes and rearrangements that occur in the vascular strands of the stem of Angiopteris. The corresponding components are similarly lettered throughout.

A. The strands in a very young sporophyte; $\mathbf{B}$ and $\mathbf{C}$ the same in older plants.

$a, b$. Parts of the siphonostele at the edge of gap caused by the exit of a lower leaf trace. The reparation of the gap is shown in the later figures of the series $A, B, C$, respectively.

c. The leaf trace strand to be given off to the next higher leaf. $x$ (in series $\mathrm{C}$ ), a commissural strand. 
lattice work differing only in the size of the mesh work from that of a typical ' polystelic' fern.

Meanwhile the leaf-traces, as has been said, increase in size, and at the same time the dichotomy above referred to extends farther and farther towards their bases till it becomes apparent almost as soon as they leave the central strand, or as we prefer to term it, siphonostele. The roots frequently originate directly from the siphonostele, though oftenest not from the margin of a gap, but rather from a broader part of the vascular tissue; they may, however, also spring directly from a leaf-trace, and in older stems they become gradually more intimately related to the latter, though a few may still spring from the axile strand itself. The latter series pursue a sinuous course through the parenchymatous ground-tissue of the stem, finally passing out through a foliar gap into the outer cortex.

The skeletal tissue now rapidly assumes a more complex character, and begins to exhibit the features appertaining to the adult form, after which the increasing thickness of the stem only produces further complication on the lines thus early inaugurated.

The traces of all but the earlier formed leaves become double from their point of exit from the siphonostele, and above each pair there is a huge foliar gap. The commissural strands which traverse the axile parenchyma of the siphonostele become more obvious, though they still are very slender as compared with the strands of which the cylinder still is made up after the exit of the traces. The latter become irregularly disposed and appear at this stage to arise from the edges of the gap, an appearance due to the deep dichotomy. They also have begun to divide up farther before entering the petiole.

Finally, the siphonostele opens out to a considerable width (Fig. 6), whilst the axile commissures assume an ever-growing importance forming a sort of sympodial column. In fact, these large commissural strands may easily be misinterpreted as representing the original stele. It is this strand which 
seems to be marked $a$ in Kühn's ${ }^{1}$ figures. The leaf-traces also become more complex, and anastomoses take place at irregular intervals with the strands which can still be recognized as the relics of the original siphonostele, as well as with one another. Irregularities also begin to become apparent as to the relative heights at which the two members of the leaf-traces become freed from the plexus of tissue, and a stage is thus reached at which the vascular skeleton appears to consist of a stout axile strand surrounded by upwardly diverging zones of steles which ultimately pass out above to the leaves. The complexity and obscurity is primarily due to the commissural strands which connect up the margins of the siphonostelic foliar gaps, and the whole arrangement is to be correlated with the presence of the bulky parenchyma of the stem.

In the much older stems, such as that described by Mettenius, the principal leaf-traces can still be recognized, in the light of what has been said, as being represented by the two stout lateral strands of the plexus which travels out to the petiole (Mettenius, loc. cit., Taf. III, Figs. I, 2, the strands lettered $a, b$ ). The smaller strands which arise between these merely form an extension of that tendency to the formation of supernumerary strands which early finds its expression in the formation of the commissures already referred to in connexion with the vascular system of the stem.

The vascular skeleton of Marattia (Figs. 7, 20) is simpler than that of Angiopteris, at any rate in young plants of equal size. The protostele opens out to form a siphonostele in a similar manner in both, but the earlier leaves are not so crowded in Marattia as in the other genus. Nevertheless the foliar gaps are relatively larger, and hence in transverse section the polystelic arrangement of vascular tissue appears more striking. The foliar gaps are also much wider than in Angiopteris and hence the siphonostele condition is perhaps not so obvious, as the impression is gained of anastomoses rather than of lack of disunion, when observed in transverse sections.

\footnotetext{
'Loc. cit., Taf. xviii and xix. Figs. 22-24.
} 


\section{of Vascular Strands in Angiopteris evecta. 379}

Sooner or later, however, commissures of an attenuated form appear in this plant also, and cross the intervening parenchyma (Fig. 7) exactly as in Angiopteris. We unfortunately had no plants old enough to enable us to follow out fully the later developments. The roots come off, so far as we have seen, from the outer surface of the siphonostele, and are even less regularly related to the leaves than is the case in Angiopteris. The leaf-traces are at first single, but those subsequently formed fork once whilst still in the stem cortex, and the dichotomy, as in Angiopteris, extends farther backward in the successively produced leaves, till it is obvious at their first origin at the base of the foliar gap.

The most striking feature of difference between Angiopteris and Marattia at this stage lies in the large diameter of the siphonostele, and the very large foliar gaps which are very characteristic of the latter genus.

Kaulfussia. The vascular skeleton has been excellently elucidated by Kühn ${ }^{1}$, and our investigations largely confirm his results. Unfortunately we were unable to secure any young plants of this genus, so we are not in a position to trace the ontogenetic evolution of the vascular strands. As might have been anticipated from its markedly dorsiventral habit and comparatively thin rhizome, the vascular system of $K$ aulfussia is much simpler than that of the other two genera, but it also exhibits features of interest which serve to illustrate some points in the anatomy of the preceding ferns. The vascular strands in the mature stem consist of an outer network from which the leaf-traces are given off on the upper side, and the greater number of the roots on the lower. This network encloses a parenchyma in which is embedded an axile vascular strand which pursues an undulating course, bending first to the upper and then to the lower face of the reticulated cylinder, with which it is alternately connected in the way described by Kühn. We regard this as certainly representing the commissural strand which occupies an exactly analogous position in both Angiopteris and Marattia, whilst

${ }^{1}$ Loc. cit.

C C 2 
we look on the peripheral mesh work as the representative of the siphonostelic cylinder in them.

The foliar gaps are large, and the leaf-trace strands plainly correspond exactly in their origin with those of the two genera already described. The two strong lateral steles, which in our specimens leave the outer edges of the lower margin of each gap; clearly represent the original forking trace which we may confidently expect the young sporophyte will be found to possess. Lying between these, and originating exactly as in Angiopteris, are a number of subsidiary strands, which anastomose both with each other and with the strong principal lateral forks of the original dichotomising petiolar steles.

Turning to the lower surface of the stem, we find diamondshaped gaps resembling foliar gaps; but in accordance with the dorsiventral habit, no leaf-traces take their origin from them. This occurrence of gaps on the lower surface is of interest as perhaps indicating that the marked dorsiventrality which Kaulfussia now exhibits, may have been acquired from a radially formed ancestor, the interior anatomical characters corresponding to such a disposition having been retained.

Both Marattia and Angiopteris also exhibit a tendency to dorsiventrality, but it is not very marked in young plants. Thus in this group, we find the skeletal framework clearly showing the original type from which they have been derived, although in external conformation the departure from the radial character has in Kaulfussia become very complete. An interesting parallel may be drawn between the Marattiaceae and the Ophioglossaceae, in which much the same range of variety can be traced. In Helminthostachys, however, the dorsiventrality which is quite as pronounced as in Kaulfussia, has also affected its internal structure, and to a more profound extent. There are no gaps at all in the lower surface of its siphonostele, and the roots are restricted to the sides and lower surface of the vascular cylinder.

In Kaulfussia, however, the commissural strand, as in the other genera of Marattiaceae, also may give rise to roots, which burrow through the parenchyma of the stem and pass 


\section{of Vascular Strands in Angiopteris evecta. $38 \mathrm{I}$}

out commonly through one of the diamond-shaped orifices on the lower surface of the siphonostele. But the great majority of the roots originate from the latter itself.

Attention has been directed by several writers to the similarity between the root-traversed cortex of Marattiaceae and the structure, apparently similar, of the fossil plants included in the genus Psaronius. In these plants the roots also seem to have passed through a parenchymatous tissue, and this fact has been utilized to strengthen the evidence based on other considerations of a possible affinity between Psaronius and Marattiaceae. Mettenius ${ }^{1}$ also briefly alludes to the comparison between the vascular systems in the two groups, but concludes that the resemblance in that respect is but slight. And on further comparing the fine series of illustrations which accompany Zeiller's ${ }^{2}$ splendid monograph, we find ourselves inclined to draw the same conclusion, in which we have been further strengthened by a study of preparations of Psaronius Renaulti, Will, and Ps. asterolithus, for which we are indebted to the kindness of Dr. Scott and Professor Oliver.

In the first place, without attaching too much weight to the abundance of the sclerenchyma in Psaronius, and its absence from the stems of Marattiaceae ${ }^{3}$, the distribution of this tissue in the fossil stems is somewhat remarkable both as regards its position and its relations to the leaftraces. The region traversed by the roots is very sharply delimited from the central tissues by a strongly defined ring of sclerenchyma, which is only broken here and there, at points where leaf-traces are in the act of passing out of the central region ${ }^{4}$. At these places the roots are absent, and it might be perhaps argued that the peripheral sclerenchyma, within the root-zone, really represented the

1 Mettenius, loc. cit., p. 5 I 7 (footnote).

${ }^{2}$ R. Zeiller, Bassin houiller et permien d'Autun et d'Épinac, fasc. ii, Flore fossile, I 890 .

${ }^{3}$ Cf. R. Kühn, Ueb. d. anatomischen Bau von Danaea, Flora, 1890. Fig. 4 .

Cf. especially Zeiller, loc. cit., Pl. XVIII, Fig. 2 ; XIX, Figs. I, 2, 3; XX, 
periphery of the stem, the petioles of the leaf dying back to this region. Zeiller not only does not figure any leaftraces as passing out through the root-zone, but in the text he expressly emphasizes their non-existence in this region. He explains their absence by supposing that, as in Caulopteris endorhiza, the original cortex was very thin, but that the parenchyma increased in amount behind the apex of the stem where the roots pass down through it. The external surface of the stem, together with the leaf-scars, is supposed to have become detached, leaving the root-traversed cortex exposed. But we find it difficult to accept this explanation without some reservation. It is not easy to see, even assuming the growth in thickness of the cortical parenchyma, how the vascular strands which originally passed through and across it, can have become so ruptured or have suffered such entire obliteration as to leave no trace of their existence, if the tissue in question is thus correctly interpreted. Psaronius, however, resembles Angiopteris in possessing, besides those roots related to the leaf-traces, others that may arise from within the central plexus of vascular strands. We have observed several instances in which they could be traced running across the cauline sclerenchyma in their outward course to join the peripheral zone of sheathing roots.

Turning to the parenchymatous tissue itself, in its relations with the roots, one is at once struck by a point of difference between Psaronius and Marattiaceae in an important particular. In the latter plants, the peripheral parenchyma of the root is sharply defined from the stem cortex, owing to the discontinuity of the tissues in development. The root is obviously an intrusive organ in the Marattiacean cortex. But in Psaronius, in the best preserved sections that we have seen, the outer cortex surrounding the zone of small-celled sclerenchyma, and forming a peripheral ring in the roots, passes almost insensibly into the parenchymatous tissue between them. Furthermore the cells of the latter are very irregular in character, often producing the effect of elongated cells 'combed' in various directions. 
of Vascular Strands in Angiopteris evecta. 383

Is it possible that these cells of the supposed cortex belong to the periphery of the roots themselves, and are really of the nature of hairy outgrowths which have become woven into a pseudo-parenchymatous tissue? Whilst retaining an open mind on this question we are inclined to see in the suggestion a solution of some difficulties, which, in the face of the evidence we have been able to collect, appear to us to render the commonly accepted interpretation somewhat inconclusive. Such a weaving of hairy tissue does actually occur to a limited extent in some tree ferns of the present day; and if the roots really did enclose the stem, instead of traversing its tissues, the mechanical advantage of such an arrangement would be obvious, and at the same time the elaborate sclerenchymatous system which appears as a mechanical anomaly in the centre of a stem at once becomes intelligible, if the outer sclerenchymatous band really marked the external limits of the young stem.

We do not raise the question as to the affinity, or the reverse, of Psaronius with the Marattiaceae generally, but only desire to point out some of the difficulties at present in the way of accepting the equivalent character of the rootzone in the two cases as having been satisfactorily demonstrated.

\section{INTERNAL STRUCTURE OF THE YOUNG SPOROPHyte of Angiopteris EveCta.}

The stem terminates below in a primary root containing a diarch vascular strand or stele (Fig. 8). The phloem is not always clearly marked from the pericycle, although with care the distinction can commonly be made out. The whole stele is surrounded by an extremely well-marked endodermis. Sometimes the protoxylem does not directly abut upon the endodermis, but may be separated from it by a layer of parenchymatous (pericyclic) cells, and the same feature may also recur in connexion with the structure of the few firstformed lateral roots, in which also a diarch or tetrarch character is retained. In the greater number of roots, how- 
ever, the protoxylem clearly extends outwards as far as the endodermis, and even in the case of those which exhibit the exceptional features just alluded to, it commonly happens that it does not affect all the xylem rays of the root.

The transition from the root to stem is accompanied by a rearrangement of the vascular constituents of the stele. The diarch xylem-plate loses its definite outline, owing to a considerable increase in the number of its tracheids that appear on the sides of the plate (Figs. 9, I0), which thus causes the wood to become roughly circular in transverse section; at the same time the protoxylem loses its individuality and thus the diarch character becomes entirely lost or obscured. The phloem also extends over the whole periphery of the wood, and in this region it consists chiefly of parenchyma, the small cells of which are very clearly defined by reason of their striking protoplasmic contents and large nuclei. Sieve-tubes may be detected here and there, but they are not numerous, and they are very different from the large and well characterized sieve-tubes in the later-formed parts of the stems of older plants. They appear in these young stems as elements with thick and densely staining walls, and possess but little contents, and are thus clearly distinguishable from the adjacent phloem parenchyma. The sieves on their walls are very plain when examined in longitudinal sections. Callus, however, so far as we have been able to discover, is absent from the sieves.

When young plantlets are examined, the tissue lying just outside the xylem is seen to be in a state of division and new elements are in this way produced, which may retain their parenchymatous character, and thus more widely sever the protophloem from the wood, or some of the cells may undergo further change and become converted into tracheids which thus reinforce the primary wood of the stele. It is easy to find in suitable material all stages in a process which represents the commencement of a secondary thickening in these plants. In older specimens this phenomenon assumes a more striking aspect, as we shall describe later on. 
Outside the phloem is a well-marked tissue bounded externally by a characteristic endodermis. The extra-phloic (pericyclic) parenchyma is cut off from a primary layer which also gives rise to the endodermis, as is so common in ferns. The parenchymatous layers internal to the actual endodermis become more numerous and easier to trace in older plants, and the common origin of the respective tissues is exceedingly clear.

The leaf-traces which pass out from this region of the stem are very simple, forming single strands, and their exit from the axile stele does not occasion the formation of foliar gaps in the ordinary sense of the expression. What happens is simply that a sector of the stele bends outwards towards the leaf, and then the loss of the tissues thus detached from the stele is at once made good above the exit of the trace.

But sooner or later the xylem ceases to form a solid axile rod. One or two parenchymatous cells appear in the centre, and form the commencement of a pith (Figs. I I, I 2). The time at which this pith first appears varies greatly. It may be present in a rudimentary form when the first leaf-traces are formed, but more commonly it does not occur until after several of these have been given off; when it has once been differentiated it increases rapidly in importance, and then the subsequently produced leaf-traces begin to become associated with foliar gaps, inasmuch as the entire thickness of the now cylindrical vascular strand becomes involved in the formation of the leaf-trace. This occurrence of foliar gaps commonly begins in connexion with the sixth or seventh leaf-trace. But there is as yet no permanent disturbance of the 'monostelic' arrangement, for the gaps continue to be repaired as fast as they occur, and no phloem or endodermis is to be discovered within the cylinder of xylem. As the leaf-traces, however, become more numerous and the foliar gaps larger, the cylindrical vascular strand loses its first character. Traces succeed each other rapidly, and before the gaps left by older ones have quite closed. In this way the annular appearance, as seen in transverse section, disappears, and several isolated 


\section{Farmer and Hill.-Arrangement and Structure}

strands apparently replace the cylindrical strand below. Furthermore, the peripheral phloem, instead of remaining as a strictly external ring surrounding the cylindrical xylem, is seen to differentiate in an intravasating manner through a gap, and thus to 'dip down,' so to speak, into the pith. Then as the gaps close up above, this phloem, which has thus become 'invaginated' into the centre is found to have disposed itself as a mantle lining the internal surface of the wood (Fig. 23). The endodermis does not necessarily take any share in the process at least in these early stages, and thus the new phloem internally borders directly on the pith-parenchyma. It is only in rather exceptionally favourable instances that this pseudo-solenostelic condition can be clearly made out in Angiopteris, owing to the fractionation of the vascular cylinder in connexion with the increasingly crowded state of the foliar gaps. In Marattia, where the gaps are not so numerous, the character is more easily observed. The phloem on the inner and outer sides of the xylem is constantly continuous through the foliar gaps, and hence the appearance, as presented in sections, is given of a change from a 'monostelic' to a repeatedly branching 'polystelic' or 'dialystelic' condition. And owing to the reparation of the foliar gaps above the exit of the traces, 'gamostely' (or solenostely) is the rule, save for the absence of the internal endodermis. As the fractionation of the vascular cylinder progresses, however, the inner phloem also may come to be lined by an endodermis, and the arrangement thus brought about coincides with that stelar arrangement termed by Jeffrey ${ }^{1}$ amphiphloic siphonostely, if the pith be regarded as excluded from the stele. We shall, however, discuss this point of view in detail further on.

It may be especially remarked here that the external endodermis is always present in all the plants of Angiopteris, Marattia, and Kaulfussia that we have examined. It is easy to demonstrate its presence by treating sections with sulphuric

${ }^{1}$ E. C. Jeffrey, The development, structure, and affinities of the genus Equisetzm. Mem. of the Bost. Soc. of Nat. Hist., v. 
of Vascular Strands in Angiopteris evecta. 387

acid, and although in Angiopteris it might escape detection if only superficially looked for, we are at a complete loss to account for these statements, constantly repeated, as to its absence in the other two genera. Kaulfussia indeed is even a somewhat favourable object on which to demonstrate its occurrence (Fig. I6), as it can readily be rendered visible by careful staining as well as by the use of sulphuric acid. The existence of an endodermis which is thus proved to be present in the Marattiaceae is a matter of some interest, as its supposed absence has been looked upon as an important differentiating character between this group and the Ophioglossaceae. But after what has been said it is clear that no such line of argument can any longer be sustained.

As has now been pointed out, the vascular tissue early loses its primitive simplicity: not only does the central strand ultimately become dialystelic (siphonostelic), but the leaf-trace strands become more complex, first by becoming forked, from the point of their origin, and in still more advanced stems by further forming an increasingly elaborate network of anastomoses by which the series of zones distinguished by Mettenius are produced. Meanwhile the commissural strands previously alluded to are formed across the central (pith) parenchyma that is still enclosed within the original fractionating siphonostelic cylinder. These commissures at their first appearance are probably secondary in origin but they rapidly acquire a considerable degree of importance in relation to the peripheral vascular cylinder. The earliest formed commissures may consist chiefly or even entirely of phloem, starting as a local hypertrophy of this tissue on the inner surface of the xylem. They become detached from it higher up; and cross over to the opposite side of the siphonostele. Here they become reinforced by xylem elements, and a leaftrace is commonly given off at the place where they join up with the tissues of the cylinder. It is, however, not very unusual to find some of these rudimentary commissural strands ending blindly in the central parenchyma, a fact which supports the view as to their secondary origin in such cases. As 
the stem grows and becomes larger, and the vascular system more complicated, the commissural strands gain in size, and completely resemble in structure that of the larger strands of the siphonostele forming the margins of the foliar gaps.

Allusion has several times been made to the addition of fresh elements to the tracheidal mass of the stele. A careful comparison with corresponding parts of the lower region of the stem in sporophytes of different ages suffices to awaken the suspicion that a secondary addition occurs in consequence of merismatic activity in the parenchyma outside the xylem ${ }^{1}$. That such is the fact is easily proved, for the new tracheids not only by their position are easily referable to their initial cells from which they respectively originated (Figs. 26, 28), but the various stages of their development may be traced with a certainty. The cells which undergo cambial division are commonly situated next the existing xylem, and they may occur singly or in groups. We have not observed any instances in which the whole parenchyma surrounding the xylem was at one time merismatic, but in favourable instances as many as six or eight such cells may be detected. The secondary wood thus formed is unimportant in amount, seldom exceeding three cells in depth, but the existence of secondary thickening in the Marattiaceae adds yet another example to those groups of Cryptogams in which it has been recognized, and shows that its presence is even less limited than has been supposed. Traces of it may still be found in larger stems, but in them it is of more isolated occurrence as compared with the younger plantlets. It is easily seen in Marattia (Fig. 22), but we have not been able to observe it in Kaulfussia.

In addition to this secondary formation of tissue within the stele, there is in Angiopteris considerable and very regular tangential division (Fig. 23) in the endodermal layer of the stem. In this way a number of radially arranged layeirs of cells are formed which may be as many as five to six in number. Commonly the outermost cell-row of this tissue assumes

1 T. G. Hill, Annals of Botany, xvi, p. I73. 
(though faintly) the characters of an endodermis. It may perhaps be urged that this is merely the tangential division of tissue which has never yet become adult, but the extreme lateness of its occurrence is opposed to such an interpretation. It was thought that the anomalous position of the sieve-tubes, which, in Angiopteris as well as in Marattia, lie outside the protophloem, might be related to this activity; but we failed to find conclusive evidence that such was the case.

In Marattia, where the same thickening of the parenchyma bordering on the stele takes place, though to a much more limited extent, only very few layers are formed. The endodermis here is usually formed from the innermost layer if there is any secondary formation at all. This endodermis is a very well marked tissue, and is interrupted here and there by curious cells resembling the 'passage-cells' met with in the roots of many plants. Commonly these passage-cells undergo several tangential divisions, but the depth of the whole number of cells thus produced does not greatly exceed that of the adjacent endodermal cells.

Passing to the apical region of the stem, in which the stelar tissues are in process of differentiation, it is observed that the xylem of the leaf-traces is endarch in position, whilst that of the larger strands of the stem is inclined to assume a mesarch character. This practically confirms Mettenius's statement ${ }^{1}$ as to the position of the spirally marked elements in cases in which they can be distinguished.

After examining a number of young plants we have come to the conclusion that the young stem possesses a single apical cell of a large size and of prismatic form, though somewhat irregular in transverse section. It sometimes has a more or less triangular form when seen from above, and it then presents a four-sided appearance. The place of origin of the leaves is clearly marked by the large apical cells which characterize their early condition.

The tannin cells which are so abundant in the leaves and roots are comparatively rare in the stem, except in connexion

${ }^{1}$ Mettenius, loc. cit, p. 5 I6. 
with the bases of these organs. In the latter they form a circle around the stele, and the cells containing the secretion are apparent at a very early age. The presence of the tannin seems to be associated with a suppression of cell divisions, for the individual cells grow to a great length as the organ as a whole increases in size. They often form chains of cells which are continuous for a considerable distance, and in some cases at least we have found evidence that the cross walls separating two adjacent cells may break down ${ }^{1}$.

The mucilage ducts, which are, unlike the tannin cells, chiefly confined to the stems in young plants, commonly make their first appearance within the pith, or horse-shoe shaped area of parenchyma which is formed when the continuity of the vascular cylinder is interrupted owing to the departure of the leaf-trace. At first, in the parenchyma exposed by the foliar gap, a mucilage duct is formed, and it dies away above, when the level is reached at which the gap is closed. Frequently, however, it branches below this, and one of the two limbs accompanies the leaf-trace for a short distance before ending blindly. The subsequently formed ducts may traverse a longer interval before ending blindly, but all of them, so far as the study of young sporophytes serves to illustrate them, are isolated and of no great length; they all divide before ending blindly, one of the arms passing out with the leaf-trace strand. They all arise lysigenously, as was stated by Kühn, at any rate in the young plants; we were not able to find any instances which admitted of explanation as having arisen schizogenously. Brebner ${ }^{2}$ has described a schizogenous origin for those studied by him in species of Marattia and Angiopteris, and Lutz ${ }^{3}$ states that their origin may be either schizogenous or lysigenous. The only instances we saw which could give rise to the appearance of schizogeny always proved to belong to the extreme upper ends of the lysigenous ducts. It would thus appear that at any rate the lysigenous origin is characteristic of the stems of the young plants, and therefore

$1 \mathrm{Cf}_{6}$ Farmer; loc. cit.

Journ. Linn. Soc., xxx.

Journ, de Botanique, xii, p. I35. 
should be regarded as the primitive type, the alternative form being, perhaps, confined to older ones. The general cortical parenchyma of the stem calls for no special mention, but it may be stated that the cells contain well-marked leucoplasts, and that their relation to starch formation can be very easily traced.

Roots. It has already been stated that the primary root is diarch. The first few lateral roots are somewhat variable in their structure, and often retain a diarch character. Then others appear which are triarch or tetrarch, and the latter are especially frequent. It is only by slow degrees that the more complex roots with their numerous rays of xylem and phloem put in an appearance. The roots arise, as has been already said, without any very definite relation to the leaves, a character which recalls the Ophioglossaceae. They also vary considerably both in old and young plants as to their attachment. Sometimes they unite with the more central strands, though far more commonly with those peripherally situated. The striking relation obtaining in Kaulfussia has already been described above.

They originate in the very young region of the stem, before it is possible to distinguish clearly the nature of the tissue from which they spring, though in all probability it should be referred to the endodermis. There appears to be a single initial cell in the first instance, of a prismatic six-sided form, and segments are cut off parallel to the elongated sides, and also from the distal end, the latter giving rise to the root-cap.

If transverse sections be examined which happen to pass through the root near its junction with the vascular tissue of the stem it will be often noticed that although as regards the radial arrangement of its xylem and phloem it conforms to the normal type of tissue arrangement, nevertheless it may exhibit an anomaly which recalls that already described for the primary and first-formed lateral roots, namely, that the protoxylem of many or even all the rays do not abut immediately upon the endodermis (which is sharply marked from the first) but are separated from it by one or more layers 
of pericyclic parenchyma. Possibly this unusual character should be correlated with the fact that the roots of these plants traverse a bulky mass of cortex before passing out to discharge their functions with which the normal structure is so obviously connected.

The cortical parenchyma of the roots whilst still enclosed in the stem-tissues frequently presents a curious appearance. The cells are elongated and their walls exhibit very regularly alternating transverse bands of thickening, the bars being separated by wider bands of unthickened wall substance. The whole somewhat recalls the scalariform markings of the tracheids, except that the bars are rather distant and the wide unthickened pits are not bordered.

Having thus considered the development and distribution of the vascular strands in the preceding stems, it still remains to attempt to correlate the structure thus elucidated more generally with the corresponding parts of other plants, and to ascertain what general conclusions, if any, can be arrived at as the result of our investigation. And at the outset of such an endeavour we are confronted by difficulties of various kinds, The most serious ones are occasioned by the divergent views which are entertained as to the 'typically' (or 'morphologically ') distinct regions of the tissues themselves; but which nevertheless form the subject-matter out of which comparative estimates are derived. Moreover, we still possess surprisingly little accurate information as to the ontogenetic evolution of the variously complex tissue-arrangements which have so often within recent years formed the subject of anatomical memoirs. The unwieldy terminology that tends to further obscure the true relations of the vascular tissues of different plants to each other is also in part due to the fact, only just beginning to become appreciated, that certain complex types may originate in different ways from the non-differentiated embryonic tissue. We are threatened with the substitution of an elaborate but purely formal description of these various types, based on a totally inadequate knowledge as to their actual genesis, in the place of a rigorous appreciation of the really 
of Vascular Strands in Angiopteris evecta. 393

essential characters corresponding to real entities, the development of which can be definitely traced, and which, stripped of subordinate details, admit of consistent comparison both with one another at the various stages of ontogeny, and also with those structures which are homologous with them in other plants.

In dealing with the attempts to frame a morphological account of the tissues it is well to recognize at once both the possibilities and the limitations which necessarily attend any efforts made in this direction. The value, morphologically speaking, of a tissue appears to us to rest on a different footing from that of an external member such as a leaf; and for this reason; that the morphological nature of the latter is, in the vast majority of instances, already determined from its first appearance as a cellular outgrowth, and is entirely unaffected by the particular course of further development which it may undergo, and equally so by the nature of the differentiation which the cells and tissues composing it may exhibit.

But in estimating the morphological nature of a tissue, or even of a tissue region, we are on much less assured ground. Our criteria only become applicable as the adult condition is reached, or when, at any rate, cellular differentiation has so far progressed that we are able to recognize the characters which will stamp the tissue at its maturity.

Even the older attempts to found a morphology of the internal regions, which explicitly started from germinal layers, or what were believed to be such, left much to be desired; and the efforts which have been made since that time to combine more or less hypothetical embryonic limits with observed ontogenetic differentiation can hardly be regarded as entirely successful. The stele, at least in the stem, admittedly corresponds for the most part with actual tissues in course of differentiation, but woven into it are other conceptions such as phloeoterma and the like, which are of a more purely subjective nature.

It is worth while dwelling for a moment on the criterion (endodermis) which is employed to limit the stele from the 
rest of the tissues that lie outside of it, and are regarded as forming no integral part of it.

The endodermis is a tissue, on the importance of which great stress is often laid, perhaps on account of its obvious characters (when present) and perhaps also because we possess so very little knowledge as to its physiological significance. And yet this same endodermis is almost whimsical in the vagaries it exhibits both in respect of its non-appearance in places where it (theoretically) should be present, as well as in its frequent occurrence in anomalous situations.

Strasburger indeed, with the acuteness that always marks his treatment of intricate problems, clearly recognized the difficulty, and he frankly abandoned the endodermis as a delimiting zone of prime morphological importance. $\mathrm{He}$, as is well known, proposed the term Phloeoterma to signify the band of tissue immediately lining the stele, and peripherally separating it from the cortex; and the existence of this phloeoterma is to be conceded; even when it cannot be objectively distinguished by special markings on its cell walls. But the special advantages of the term would really appear to be involved in a tacit assumption of its coincidence, or analogy, with the older form of demarcation as laid down by Hanstein. The latter writer, at least by implication, went farther back than the differentiating tissues to the meristems from which they took their origin. So long as 'monostely" alone is concerned the phloeoterma may serve, but in cases of polystely and schizostely, where it might be of critical value, it seems to possess but little advantage over the endodermis itself. For to put one of several aspects of the case, why should the entire limiting layer of vascular strands containing $\mathrm{I}+n$ bundles be regarded as a phloeoterma, whereas if there be but I bundle in the strand, part must be regarded as phloeoterma and the rest as endodermis? What is the special value of the addition of $n$ bundles, that it should so alter the conception as to the 'morphological' nature of the sheath? But the confusion becomes incomparably more profound when the vascular continuity of the main cylinder or 
strand becomes interrupted as the result of the exit from it of the leaf-traces. Taking a 'medullated monostele' as the simplest case, the xylem at this period forms a cylinder of wood enclosing a pith or axile core of parenchyma, and is itself ensheathed in a continuous ring of phloem outside of which the endodermis is situated. For a time the gaps due to the exit of the vascular elements of the leaf-trace continue to be repaired, but sooner or later the reparation becomes insufficiently rapid, and a differentiation of phloem may proceed to extend round the edges of the gap and coat the inner face of the xylem. This may be, and usually is, accompanied by a similar differentiation of endodermis. Henceforth; the central parenchyma is no longer regarded as belonging to the stele, although it may continue to occupy the same position in the vascular cylinder taken as a whole, but is considered as now belonging to the cortex of the stem. Essentially it is the 'extension' on the part of the phloem and endodermis, but especially the latter, which has made the difference. The various forms of polystely, dialystely, schizostely, with their correlatives gamostely and gamodesmy, merely form variants of the process depending respectively on the degree of union or separation of the vascular constituents.

It may happen, however, that the development proceeds on somewhat different lines, and that within the vascular cylinder phloem or endodermis, or both, may be differentiated within the xylem from the whole or the peripheral portion of the axile parenchyma. In this way are produced the various

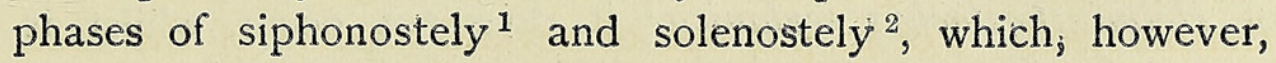
become indistinguishable from the other above-mentioned types of stelar arrangement, as soon as the continuity of the tissues has been broken by the foliar gaps.

Jeffrey's conception of the siphonostele ${ }^{3}$ was designed to

${ }^{1}$ In the sense of the term as employed by Jeffrey.

a Cf. Gwynne-Vaughan, Observations on the Anatomy of Solenostelic Ferns. Annals of Botany, xv, p. 73:

${ }^{3}$ E. C. Jeffrey, The development, structure, and affinities of the genus Equisetum. Mem. of the Boston Soc. of Nat. Hist., v, p. 160.

D d 2 
embrace those cases in which the vascular tissues had passed out of the protostelic condition (in which a solid core of xylem occupies the axis of the stele), but he retained the inner endodermis as an essential constituent delimiting the inner region of the stele from the axile parenchyma, which he rightly, as we think, regards as not belonging to it.

We regard this as a step in the right direction, but in our opinion Jeffrey has not gone far enough. The great advantage which the idea of the siphonostele possesses over that of the monostele for us, lies in the emphasis which it throws on the unity of the vascular tissue as a whole as opposed to the circumjacent ground-parenchyma, instead of merely laying stress on one particular arrangement or collocation of tissues which may or may not be preserved in its integrity according to the nature, firstly, of the foliar gap development, and secondly, of the internal differentiations which may occur in connexion with them. We prefer, as a preliminary step, to dissociate the stele altogether from the endodermis which is certainly not always present. For us it is a matter of absolutely subordinate importance whether there is an internal endodermis or not; and, so far as we know, there is no inherent or a priori need of postulating its theoretical existence when it cannot be objectively demonstrated.

The inherent weakness of the position which relies on the existence of an internal endodermis, as forming an essential zone of demarcation of the stelar tissue from the medullary parenchyma, is rendered manifest by many test cases in which it may or may not be present. Thus in the young rhizome of Helminthostachys zeylanica ${ }^{1}$ it does not occur, whilst it appears fitfully and irregularly within the steles of older plants.

Again, the case of the genus Botrychium is of interest in this connexion. Van Tieghem ${ }^{2}$ regarded the stem of $B$. lunaria (together with the other members of the Ophioglos-

1 Farmer and Freeman, On the Structure and Affinities of Helminthostachys zeylanica. Annals of Botany, xiii. Cf. also W. H. Lang, Prothalli of Ophioglossum pendulum and Helminthostachys zeylanica. Annals of Botany, xvi, p. 43 .

- Van Tieghem, Remarques sur la structure de la tige des Ophioglossées. Journ. de Botanique, t. iv. 
saceae investigated by him) as monostelic up to the formation of the first leaf. Above this an internal endodermis appears; and the arrangement becomes in consequence astelic, and, from the mode of grouping of the individual bundles, gamodesmic. But in B. virginianum, according to Jeffrey ${ }^{1}$, the medulla is not separated from the xylem by an internal endodermis, and thus, to use the terminology of Van Tieghem, there is a perpetuation of the monostelic condition. That is, in closely related forms there exists a fundamental difference in the 'morphological structure' of their stems, as decided by the criterion of the endodermis.

Perhaps, however, the best examples of its irregular distribution are afforded by the Osmundaceae which have recently been investigated by Faull ${ }^{2}$. The stems of these Ferns are siphonostelic, the vascular tissue being arranged in a cylindrical fashion round an axile pith. But it is only in one species, $O$. cinnamomea, that this pith is delimited by an endodermis from the vascular strand. It is on this ground that the Osmundaceae are held to be siphonostelic, and the absence of the endodermal criterion is looked on as a consequence of degeneration, a view which seeks support in the occasional presence of internal phloem (also confined to this species) which is, however, restricted to the regions where the stem is forking. We question the legitimacy of the argument, and dissent from the conclusions as to degeneration. But we entirely agree with the author in the appropriateness of the term siphonostele as applicable to the vascular tissues of the stems of all these plants, though our reasons, as will have become apparent above, are not quite identical with his own.

By thus emphasizing the vascular tissues as the feature of paramount importance, the pith is reduced to a subordinate position, similar to that which it occupied in the systems of De Bary and Sachs. But we become the gainers at least

1 E. C. Jeffrey, The Gametophyte of Botrychium virginianum. Trans. of the Canadian Institute, v, pp. 283-4.

${ }^{2}$ Faull, The Anatomy of the Osmundaceae. Botanical Gazette, xxxii. 


\section{Farmer and Hill.-Arrangement and Structure}

in this, that we are thereby emancipated from the highly artificial considerations such as begin by regarding the pith as an integral part of the unit (the monostele), and then proceed to disregard or deny its further existence as soon as the peripheral mantle of phloem, pericycle, or endodermis shall have extended around the inner face of the xylem. Such a point of view seems to us to originate in and depend upon a one-sided and abstract contemplation of isolated transverse sections, and to omit all reference to the mutual relations of the tissues to each other, as continuous and concrete realities in the body of the plant. By concentrating attention on the vascular strand as the thing of real importance, whether it be present in the form of a solid rod (protostele) or as a hollow cylinder (siphonostele), one is equally concerned with a definite unit, and the various transitions to polystely, \&c., become clearly referable to a single plan, and their several relations become at once obvious. It is the inclusion of the pith as an integral part (which has to be subsequently discarded) together with a strained and artificial criterion as to the boundary of the stele, that seem to us the fatally weak points in the whole stelar theory, and which have resulted in unnatural interpretations being given in not a few instances of structures that do not conform to the more ordinary types of stem structure.

It may, perhaps, be objected that inasmuch as all gradations may be traced between a xylem parenchyma that is intermingled with tracheids, and a true pith such as forms the core of a 'medullated monostele,' this in itself constitutes a sufficient reason for not dissociating it from the vascular tissues in defining our conception of the stele. Similar objections could probably be urged against most morphological distinctions, and certainly against all which are affected by tissue differentiation. The whole matter is really a question of consistency and convenience. If the inclusion of the pith in the stele is, however, no longer conducive to a clear comprehension of the latter in its comparative relationships, and still more if it can be shown rather to obscure them, 
then it is best to enforce the distinction. In any event, to render its inclusion or exclusion contingent on the differentiation of a zone (endodermis) notoriously uncertain, and inconstant even in nearly related forms, appears to us as a gratuitous introduction of a confusing element into a subject already sufficiently provided with artificial difficulties.

It would appear to be probable that no right understanding of a difficult vascular structure is possible apart from a study of its ontogenetic development. Only in this way can the complex arrangements, such as may occur for example in the stems of many lianes, be understood and referred to the relatively simple condition typical of the great majority of dicotyledons.

But although we are unable to accept, at least in their entirety, the views held in many quarters as to the morphological relations assumed to subsist between the various tissues, we are far from underrating the value of evidence derived from a study of comparative anatomy in dealing with questions of affinities. On the contrary, we are completely in accord with those who regard such evidence, when properly sifted and checked, as of great value; and it is largely on this very account that we have felt bound to state our grounds for diverging from the opinions entertained by many others as to the importance of the quasi-morphological relationships of the various tissue-systems to one another. But, as with all characters, the value of those which can only be distinguished by the aid of a microscope requires to be appreciated with caution and applied with care. Perhaps, indeed, anatomical characters need this even more than most others, on account of the relative ease with which so many of them are apparently susceptible to alteration or suppression.

To return to the structure of the Marattiaceae, we may summarize our results as follows. The stem of Angiopteris, and that of Marattia is in close agreement with it in all essential respects, contains in the young plant a single solid protostele. In the centre of the xylem, certain cell-rows cease to differentiate as tracheids, but proceed to give rise 
to a parenchymatous pith which we regard as distinct from the now tubular stele. The latter forms at this stage a hollow cylinder or siphonostele, although in using the latter word we do not, as already explained, attach to it precisely the same meaning as Jeffrey did when he originally defined it. Nevertheless our own view forms so simple an extension of that put forward by the Canadian botanist, that we have not hesitated to retain his terminology in preference to coining a new word.

The siphonostele thus formed becomes more or less broken up, giving rise to those kinds of vascular arrangements which have been elsewhere designated as 'polystelic' or 'dialystelic,' as well as to the concomitant appearances of 'gamostely' or 'solenostely' as the foliar gaps are intermittently repaired.

The earliest important change in the arrangements of the siphonostelar tissues results from a differentiation, in a more or less continuous sheet, of phloem on the internal face of the xylem. We have not, as already stated, succeeded in making out a good case for the occurrence of a regular internal endodermis, except as a late and purely secondary occurrence, and it is in this respect that our plant in its earlier stages departs, objectively, from the siphonostelic condition as defined by Jeffrey. Such a departure is not very uncommon amongst the Ferns. We have alluded to the case of the Osmundas, and Schizaea ${ }^{1}$ supplies a similar example. The tubular vascular strand is not delimited from the pith by any special layer, nor is there any internal phloem. On the other hand, the young plantlet of Aneimia phyllitidis ${ }^{2}$ only resembles Angiopteris in the protostelic stage. Its subsequent condition is solenostelic, or it might also be cited as an example of amphiphloic siphonostely in Jeffrey's sense. Internal phloem and endodermis are, however, developed in this plant directly, in contradistinction to what obtains in Angiopteris, as a differentiation of intraxylar tissue without reference, in the first instance, to the external corresponding tissues of the

1 L. A: Boodle, On the Anatomy of the Schizaeaceae. Annals of Botany, $\mathrm{xv}, \mathrm{p} .373$.

B Boodle, loc. cit. 
of Vascular Strands in Angiopteris evecta. 40 I

foliar gaps. It is only subsequently that the inner and outer phloem and endodermis become united by way of the leaf gaps. In Angiopteris, as has already been pointed out, the internal phloem clearly arises in relation to, and in consequence of, the occurrence of the leaf gaps. Again, in Platyzoma microphyllum ${ }^{1}$ there is no internal phloem, but a well-marked endodermis, whilst in Helminthostachys there is only an irregular internal endodermis in the older stems, the young plants being quite destitute of any tissue, apart from pithparenchyma within the xylem. The latter point is singular, since, according to Poirault ${ }^{2}$, precisely the reverse obtains in Botrychium. But it is of interest to note that, in spite of these very diverse modes of development and of completeness, the siphonosteles all exhibit, as seen in transverse sections, the 'polystelic' or 'dialystelic' condition in consequence of the enlargement and frequency of the foliar gaps.

The examples thus quoted might be greatly extended and amplified; they may serve to show how readily the vascular system of the Ferns may be treated from a comparative standpoint, if the salient and more permanent features are clearly divested of variable details of subordinate importance; and in this connexion the principal characters and mode of fractionation of the vascular strands and the primary relation of the process of the leaf gaps is clearly of first-rate importance. Cases of apparent exceptions, e.g. Kaulfussia, in respect of the ventral gaps in the siphonostele, are readily brought into line with the rest. But the degree of importance of this or that tissue in the composite strands themselves is shown by comparative anatomy to be a feature of minor significance, inasmuch as considerable variations may exist not only in related forms, but also in the body of one and the same individual.

1 Boodle, On the Anatomy of the Gleicheniaceae. Annals of Botany, xv, p. 735.

${ }^{2}$ Poirault, Rech. anat. sur les Cryptogames vasculaires. Ann. Sci. Nat. (Bot.), sér. 7 , t. xviii. 


\section{Farmer and Hill.-Angiopteris evecta. \\ EXPLANATION OF FIGURES IN PLATES XVI, XVII, XVIII.}

Illustrating Professor Farmer and Mr. Hill's paper on the arrangement and structure of the vascular strands in Angiopteris evecta, \&c.

\section{Abbreviations.}

a. apical cell; $c b$. cambium; com. commissure; c.t. (Fig. 22) crushed tissue; end. endodermis; $f_{0} g$. foliar gap ; l.t. leaf.trace; $p$. parenchyma ; ph. phloem; p.r. primary root; $p . x$. protoxylem; $r t$. root ; $r . a$. apical cells of root; st. stele; s.t. sievetube $; t .2$. secondary tracheids; $t . s$. tannin sac; $x$. xylem; $x$.p. xylem parenchyma.

Fig. I. Young stele of Angiopteris evecta, side view ( $x$ about 50 ).

Fig. 2. Older stele, two foliar gaps are seen near the apex.

Fig. 3. Portion of stele of older plant showing the foliar gaps.

Figs. 4, 5. Two different views of the stele of a still older plant showing the transition from the preceding simple, to a more complicated, structure. (The numbers of the roots and leaf-traces refer to the same individual members in the two figures.)

Fig. 6. Stelar system from a much older plant. (The natural proportion between the length and breadth is here somewhat exaggerated, in order to render the parts more distinct.)

Fig. 7. Upper portion of a siphonostele of Marattia fraxinea viewed obliquely from above; $X$ I 2 (cf. Figs. 20 and 21 ).

Fig. 8. Transverse section of the primary diarch roat of Angiopteris.

Fig. 9. Section from the same root in the transitional region between root and stem.

Fig. Io. Section from the same still higher up showing formation of intraxylar parenchyma.

Figs. II-I3. Angiopteris. Transitional region from another series showing formation of a pith ( $x$ I 70 ).

Fig. I 4. Longitudinal section or apex of stem of Angiopteris showing apical cell.

Fig. 15. Transverse section of apex of stem of Angiopteris.

Fig. I6. Kaulfussia aesculifolia. Transverse section of stele showing endodermis.

Fig. I7. Angiopteris. Transverse section of stem showing the exit of a leaf-trace, $i t$., and the fusion of a root stele, $r t$., with the central strand.

Fig. I 8. Angiopteris. The origin of a root in the apical region of the stem. $x$.a. Root apex.

Fig. 19. Angiopteris. Central strand, roor, and leaf-trace, with sieve-tubes within the stele.

Fig. 20 (cf. Fig. 7). Marattia. Stelar system as seen obliquely from above.

Fig. 21. The same viewed from the side.

Fig. 22. Marattia. Transverse section of stele in the stem, showing merismatic tissue. Endodermis well marked.

Fig. 23. Angiopteris. Transverse section of the stem with secondary tracheids and an internal phloem.

Fig. 24. Angiopteris. Leaf-trace.

Fig. 25. Same with increased development of xylem $(x 290)$.

Figs. 26, 28. Angiopteris. Transverse section of stem, showing secondary formation of tissues.

Fig. 27. Angiopteris. Division in extra-stelar tissue, Longitudinal section of the stem. 
Annals of Botany
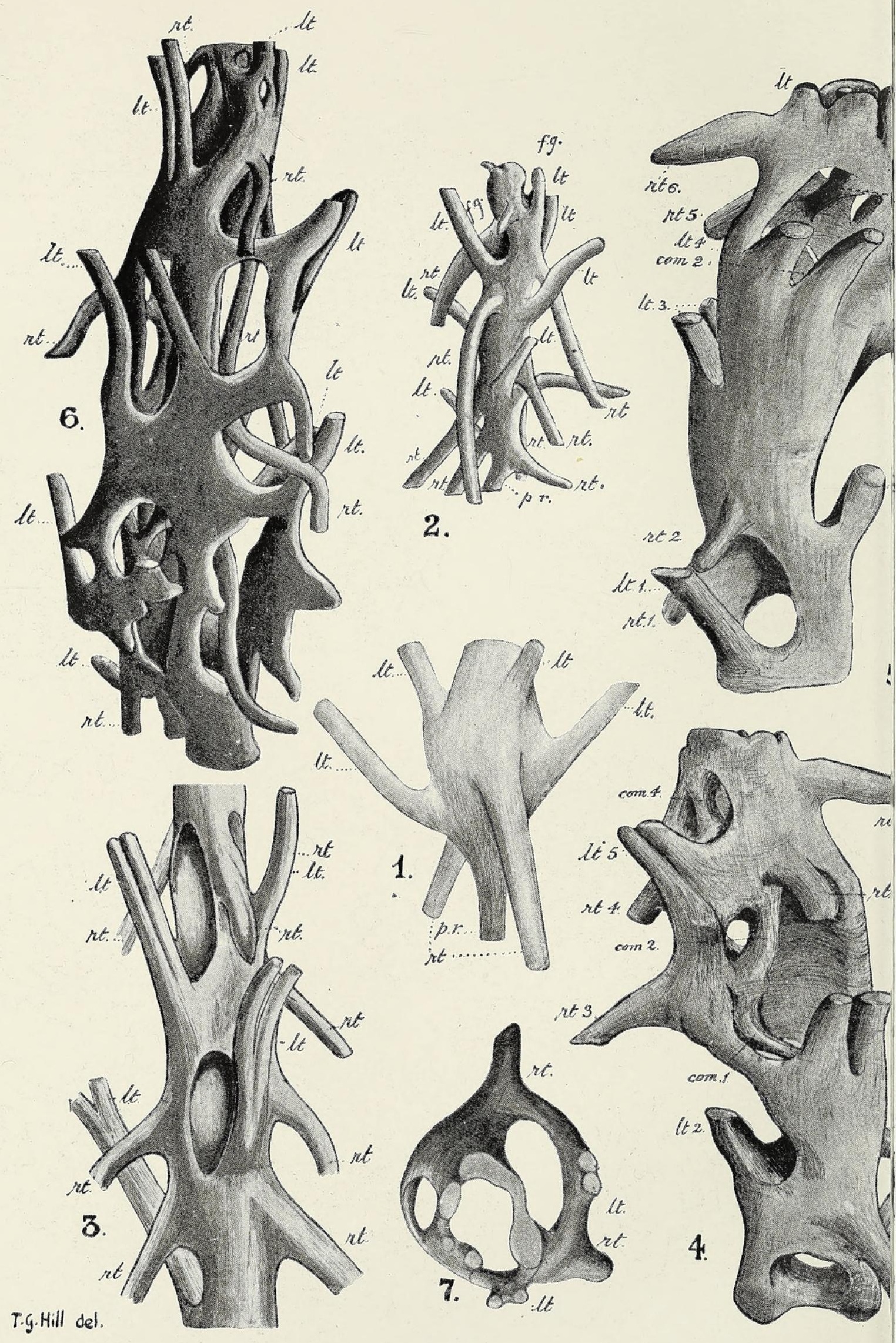

1.
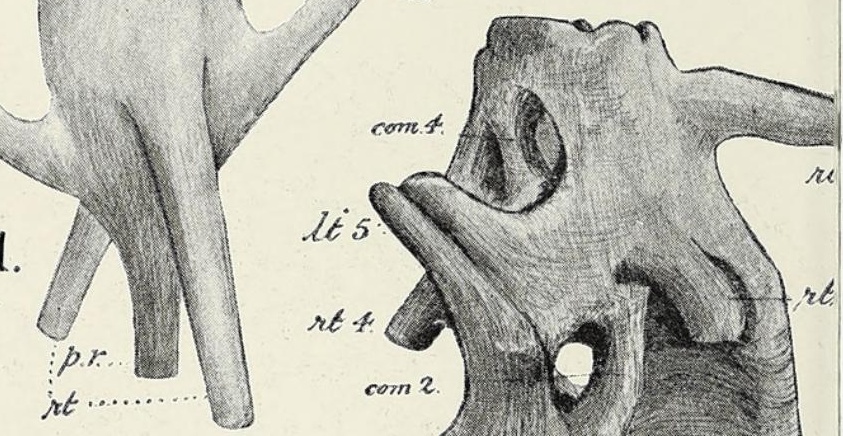

T.G. Hill del.

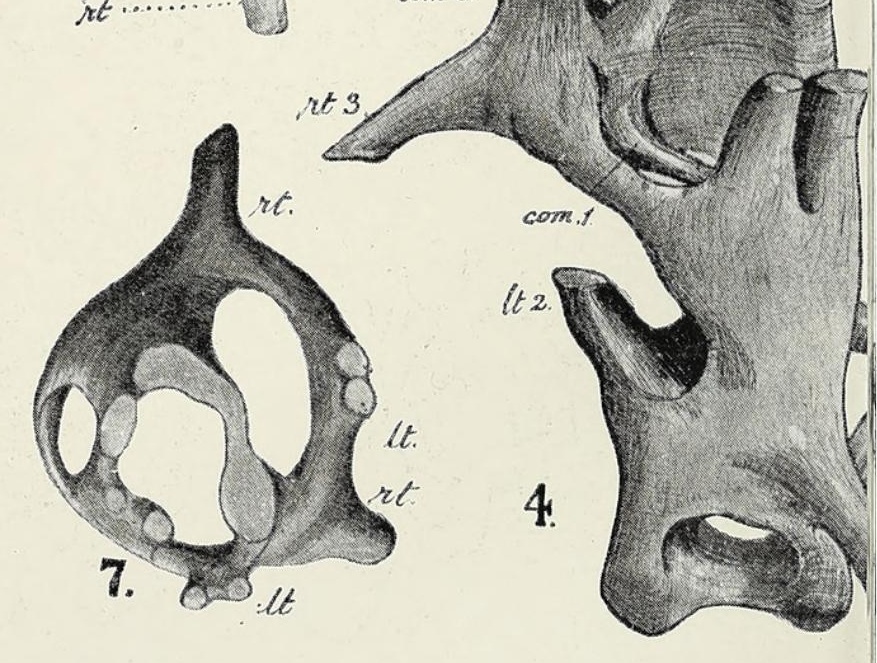


Vol. XVI, Pl. XVI.
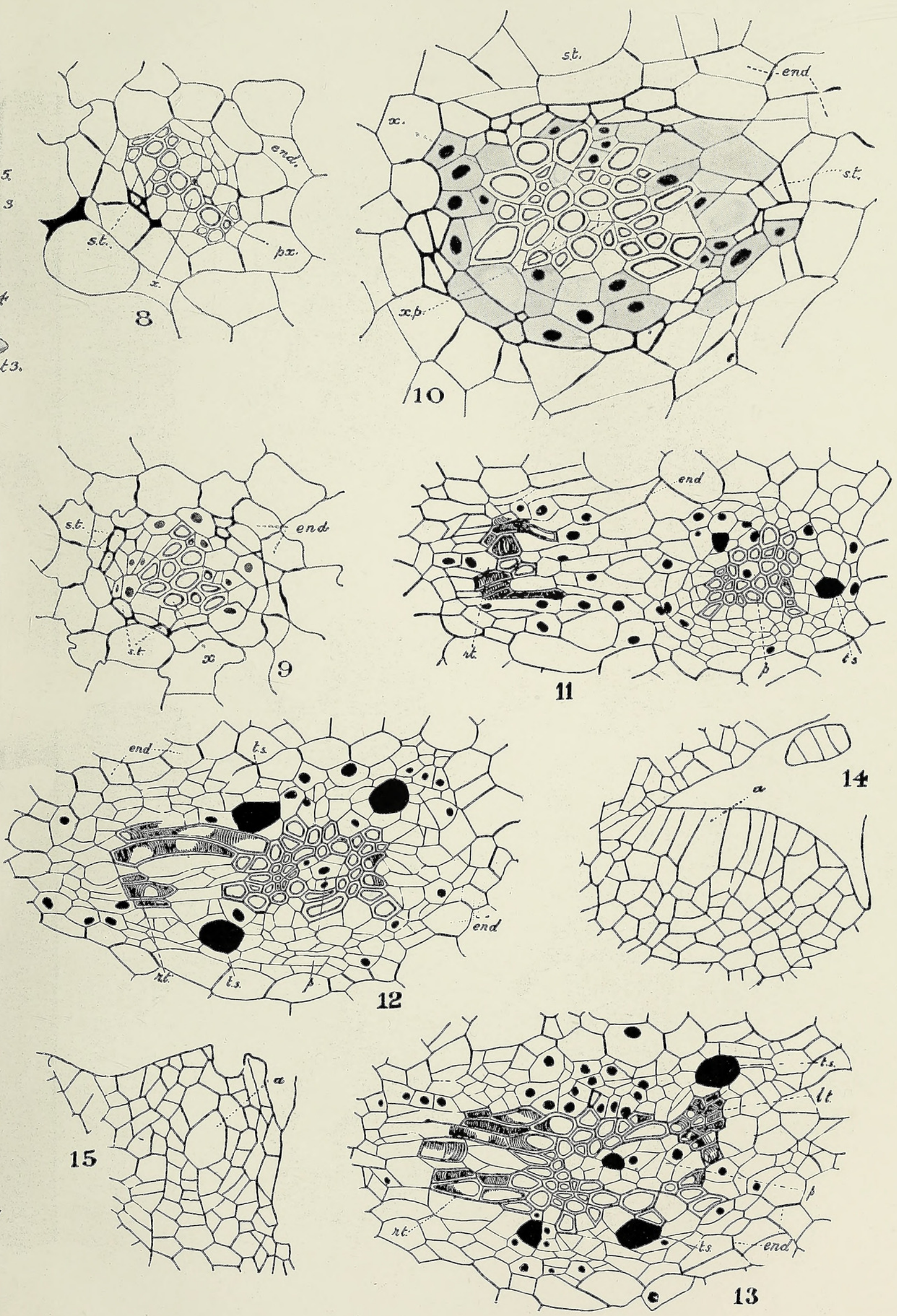

OMY OF MARATTIACEAE. 


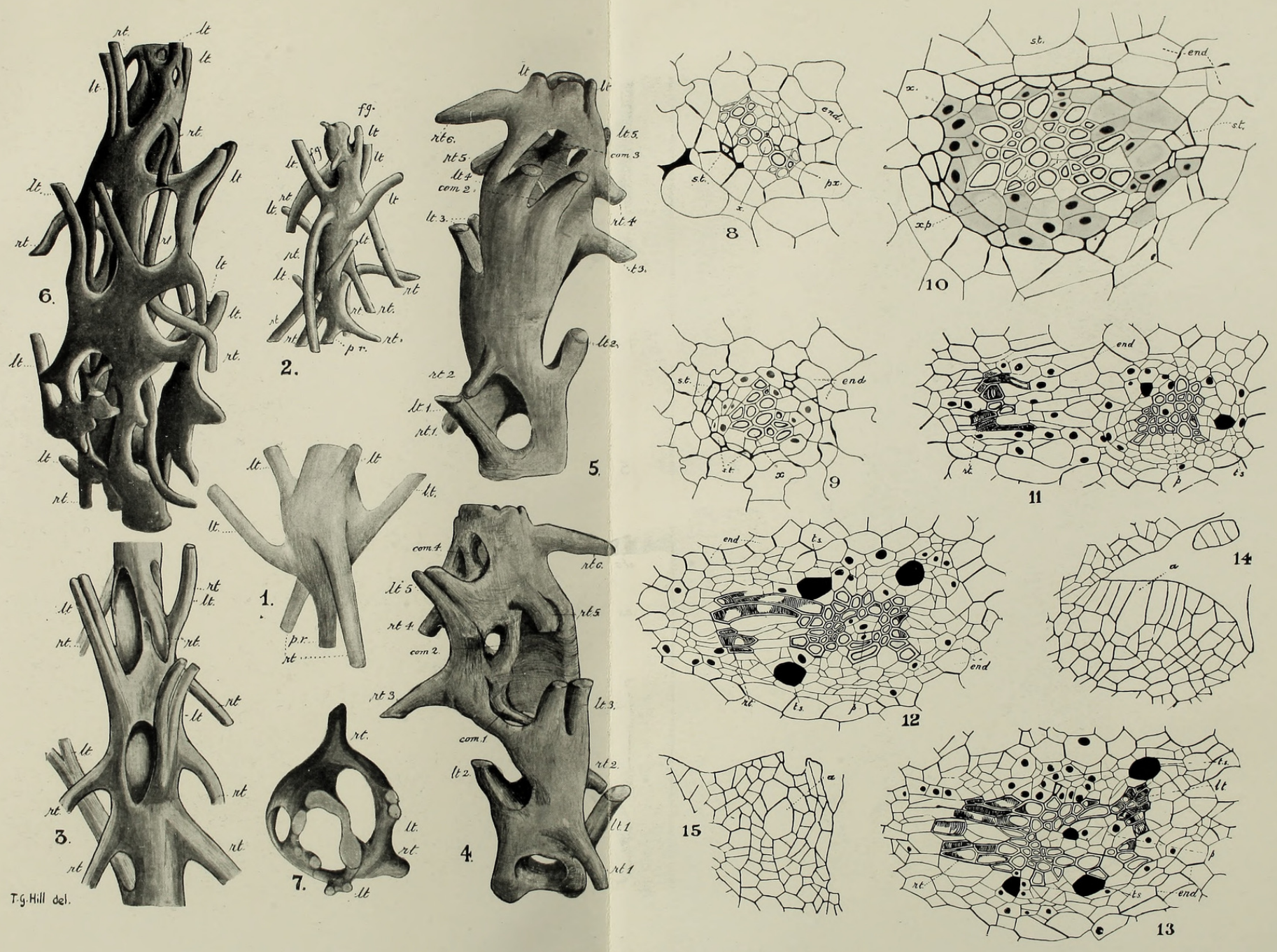



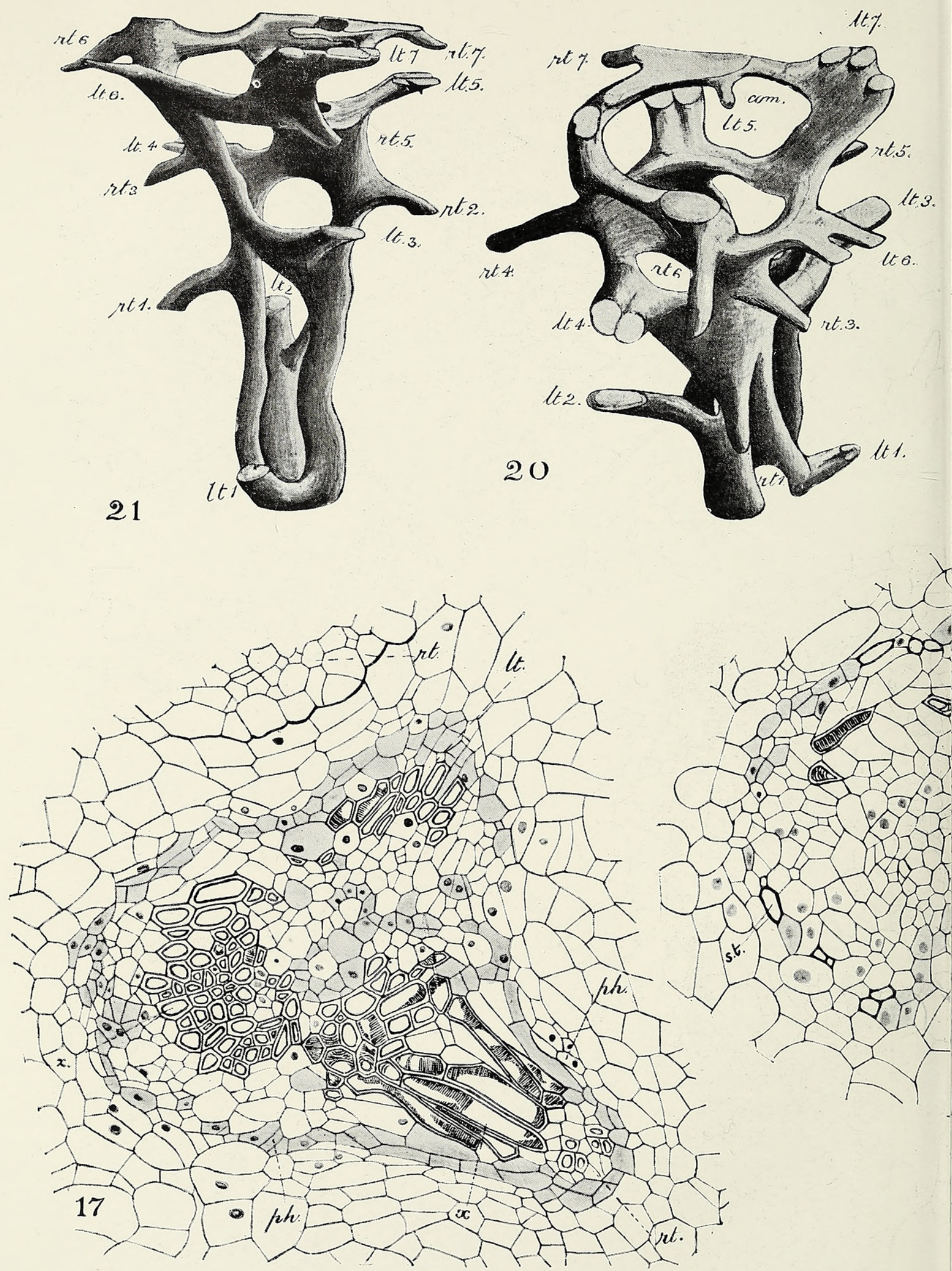

T.g.Hill del. 
Vol. XVI, Pl. XVII.

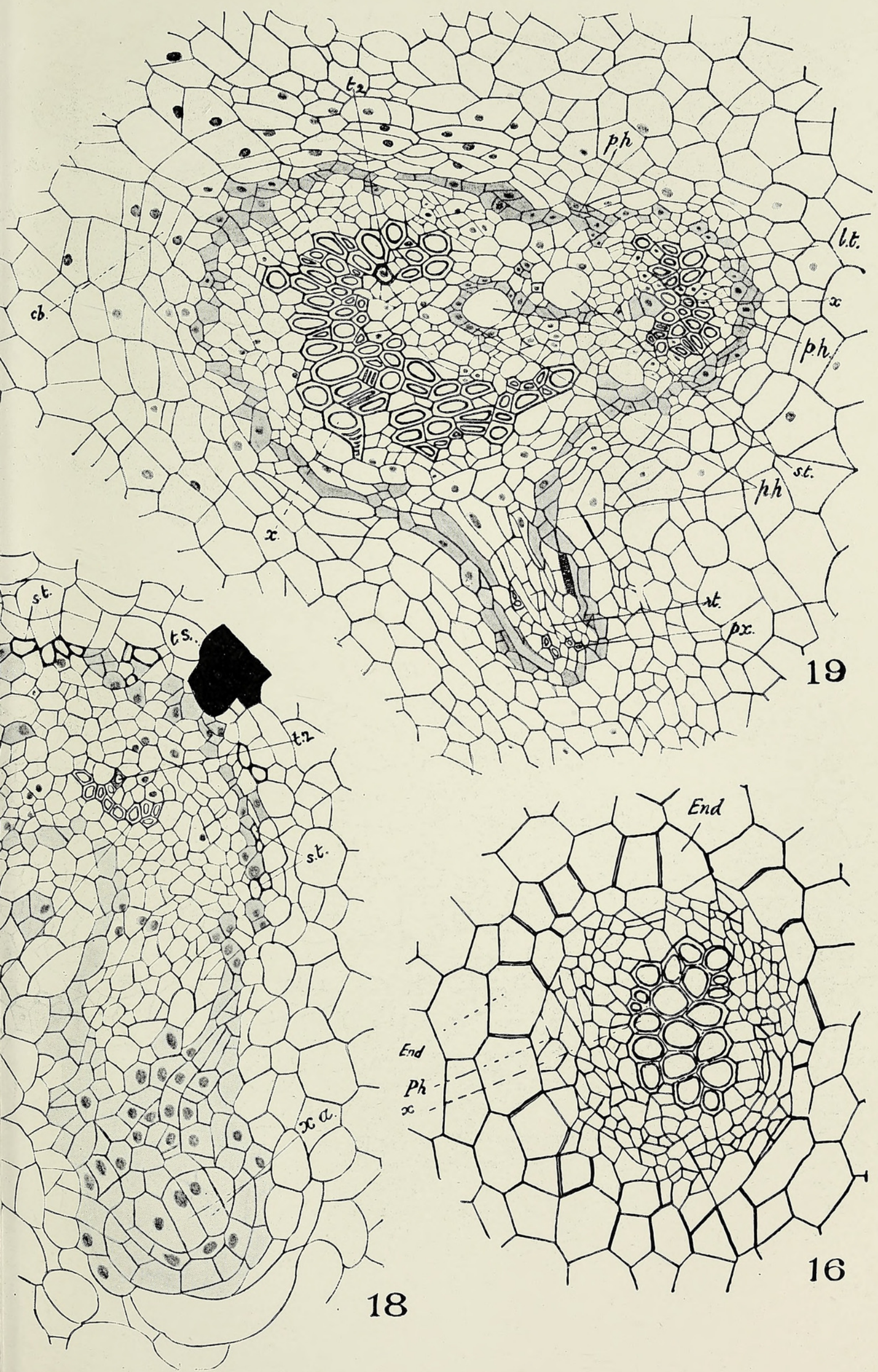

Y OF MARATTIACEAE. 

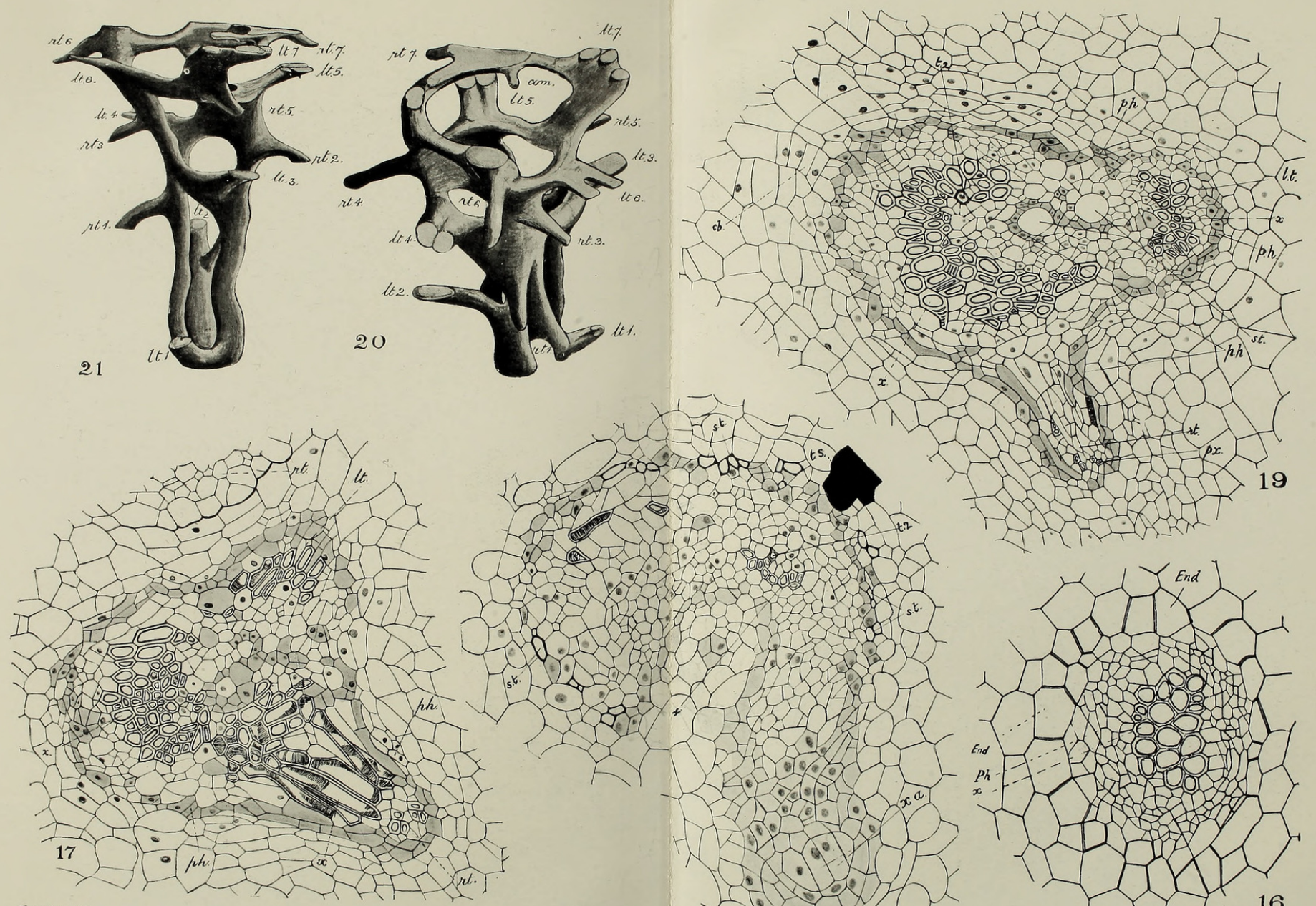

T.G. Hill del.
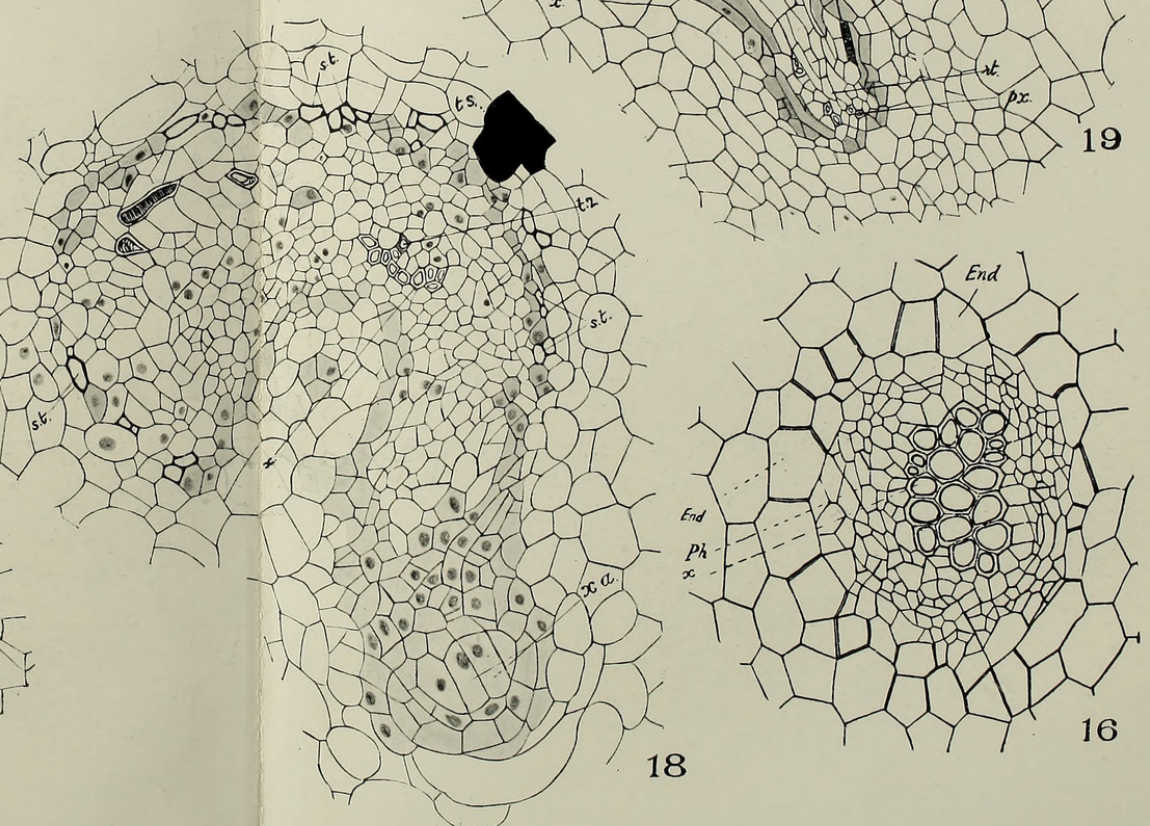


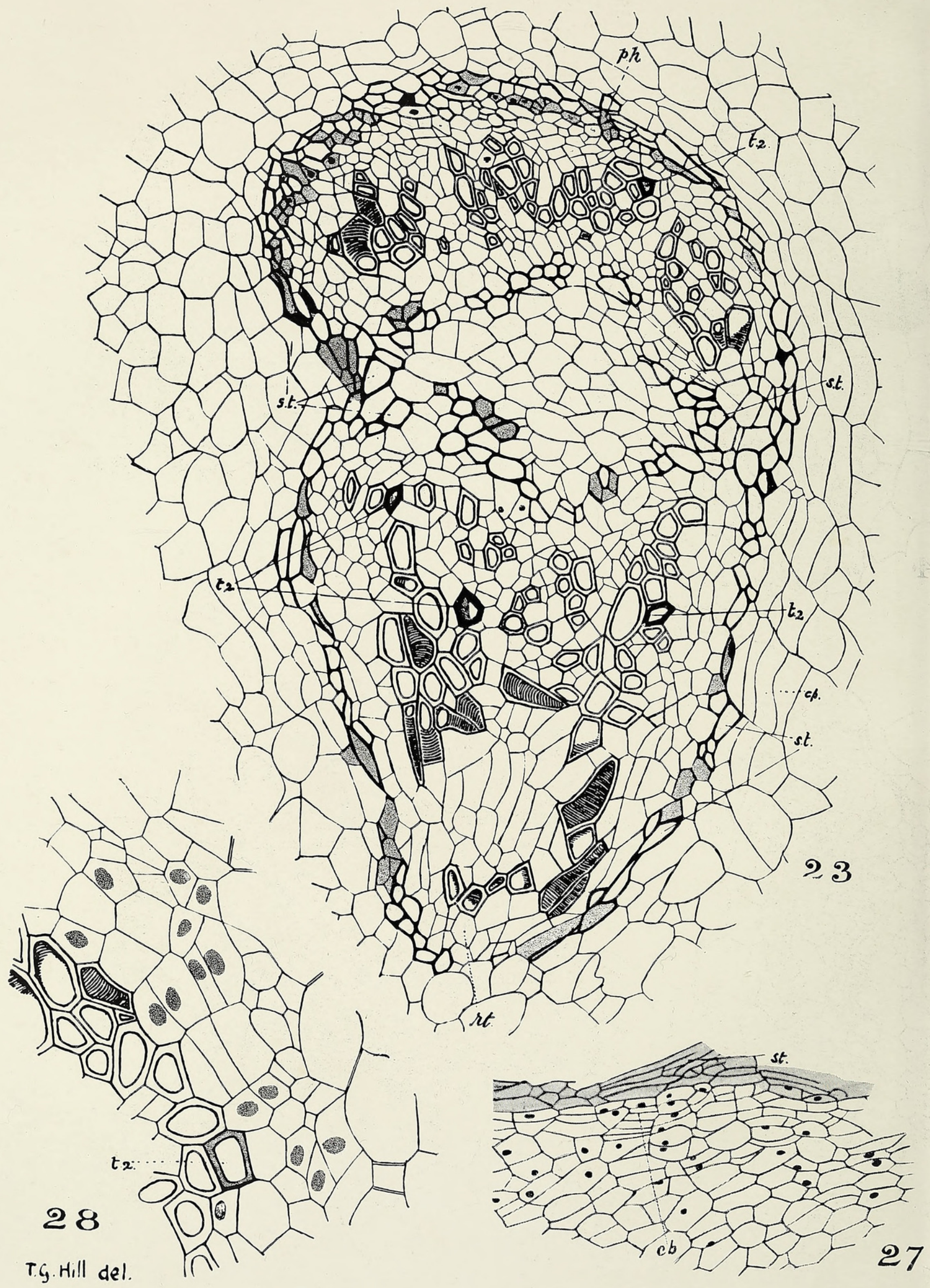



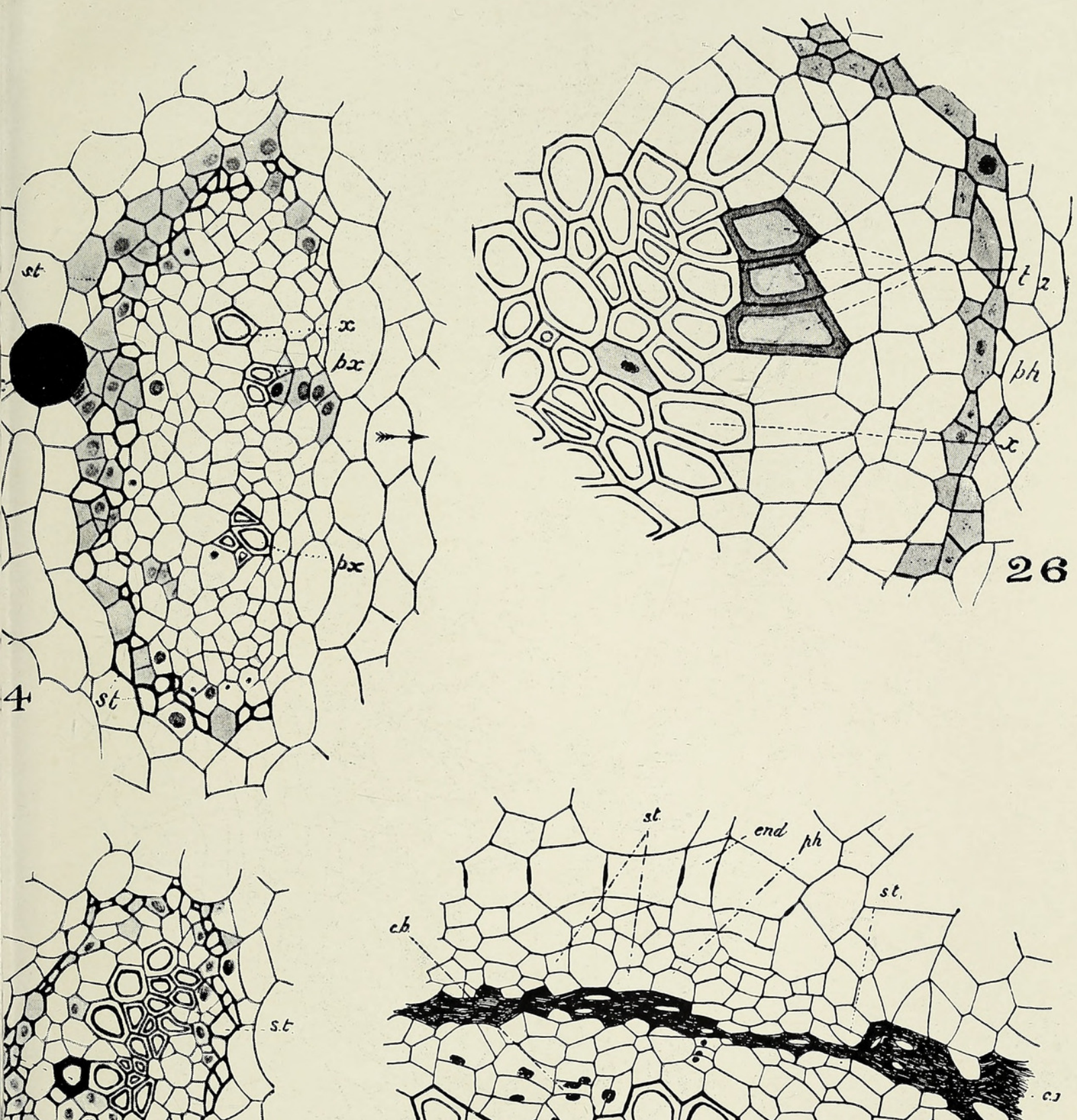

1 -

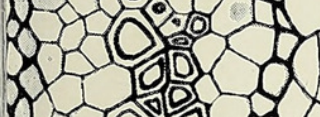

301013
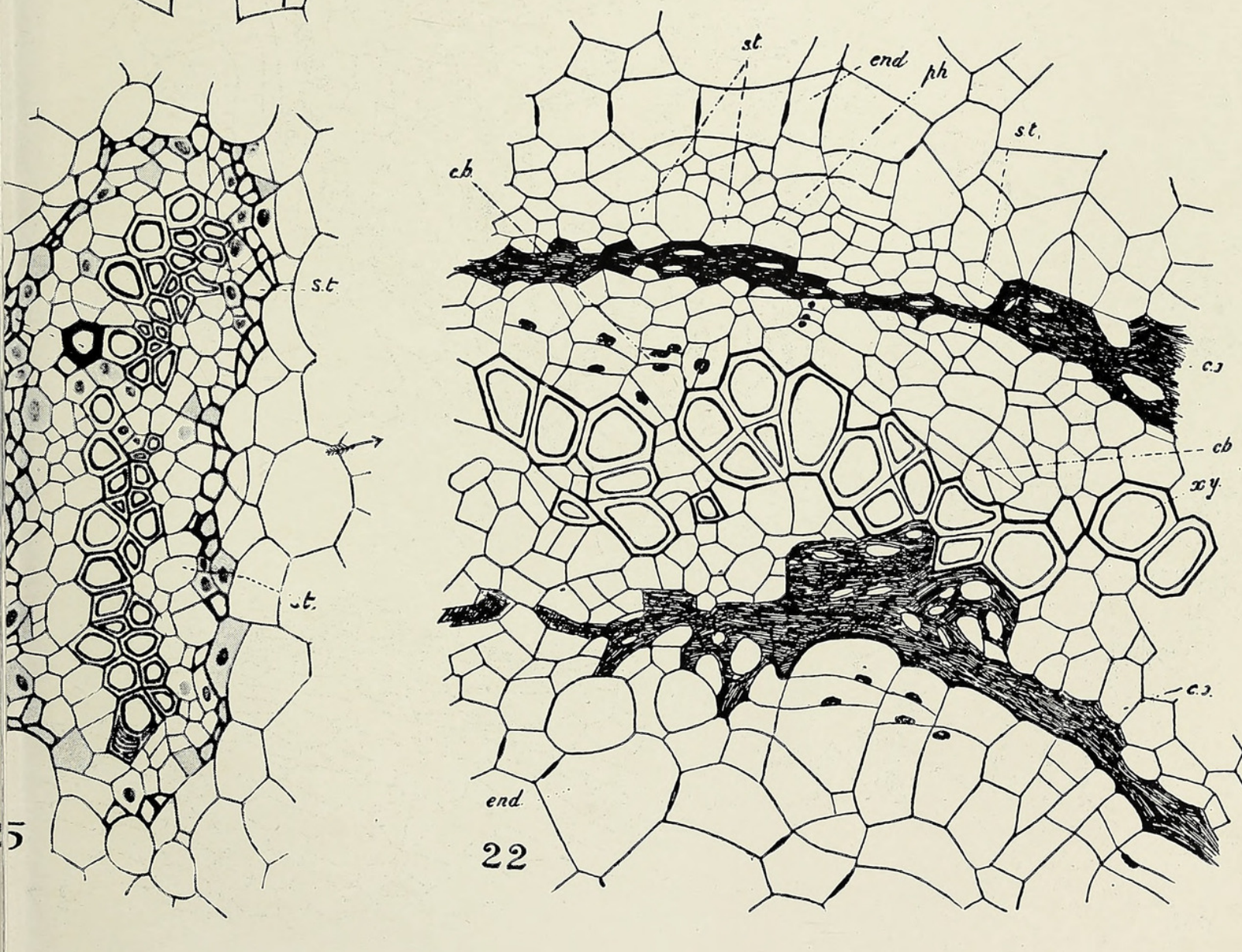


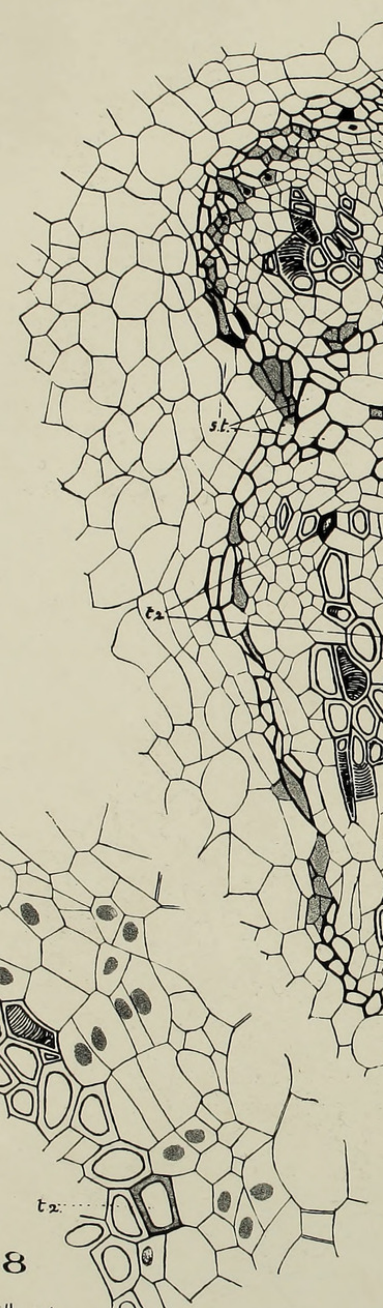

TG. Hill del.

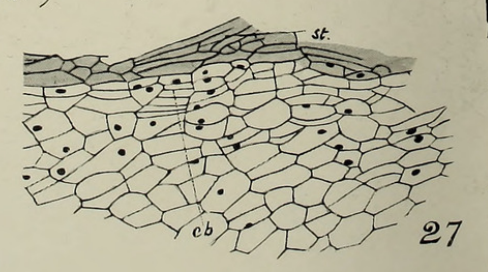

FARMER AND HILL.-ANATOMY OF MARATTIACEAE.

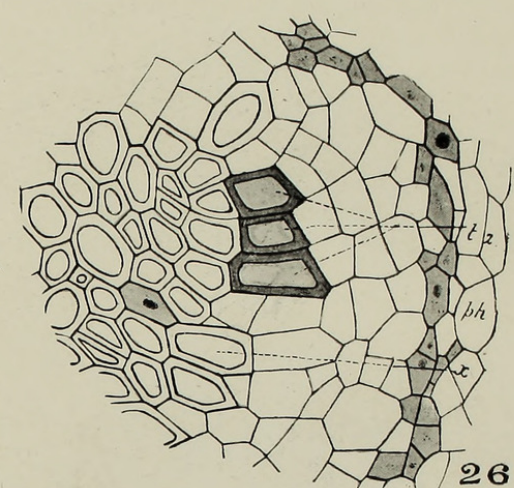

24 siteres

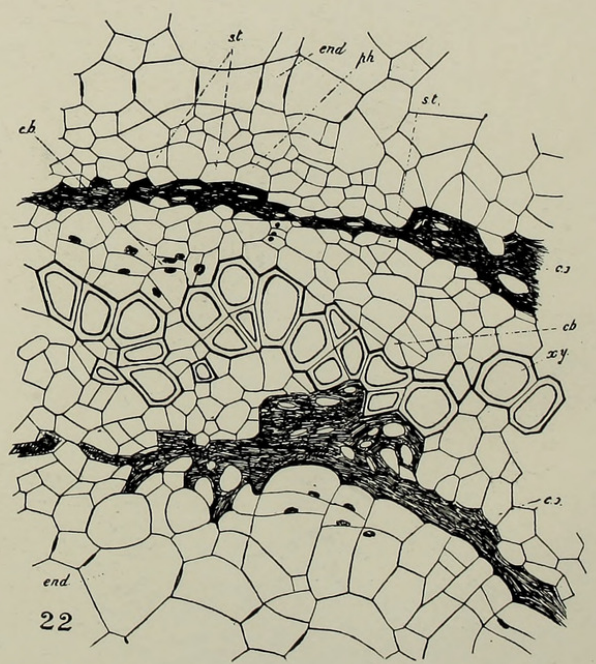




\section{$2 \mathrm{BHL}$ Biodiversity Heritage Library}

Farmer, J. B. and Hill, T. G. 1902. "On the arrangement and structure of the vascular strands in Angiopteris evecta, and some other Marattiaceae." Annals of botany 16, 371-402. https://doi.org/10.1093/oxfordjournals.aob.a088878.

View This Item Online: https://www.biodiversitylibrary.org/item/233980

DOI: https://doi.org/10.1093/oxfordjournals.aob.a088878

Permalink: https://www.biodiversitylibrary.org/partpdf/318679

\section{Holding Institution}

Smithsonian Libraries

\section{Sponsored by}

Biodiversity Heritage Library

\section{Copyright \& Reuse}

Copyright Status: Not in copyright. The BHL knows of no copyright restrictions on this item.

This document was created from content at the Biodiversity Heritage Library, the world's largest open access digital library for biodiversity literature and archives. Visit BHL at https://www.biodiversitylibrary.org. 